University of Wollongong

Research Online

Faculty of Engineering and Information

Faculty of Engineering and Information

Sciences - Papers: Part B

Sciences

2020

\title{
Biogeochemical Clogging of Permeable Reactive Barriers in Acid-Sulfate Soil Floodplain
}

Buddhima Indraratna

University of Wollongong, indra@uow.edu.au

Subhani Medawela

University of Wollongong, skmsj997@uowmail.edu.au

R Rowe

Ngamta Thamwattana

University of Wollongong,ngamta@uow.edu.au

Ana Heitor

University of Wollongong, A.Heitor@leeds.ac.uk

Follow this and additional works at: https://ro.uow.edu.au/eispapers1

Part of the Engineering Commons, and the Science and Technology Studies Commons

Research Online is the open access institutional repository for the University of Wollongong. For further information contact the UOW Library: research-pubs@uow.edu.au 


\title{
Biogeochemical Clogging of Permeable Reactive Barriers in Acid-Sulfate Soil Floodplain
}

\author{
Abstract \\ (C) 2020 American Society of Civil Engineers. Column experiments that investigate the use of calcitic \\ limestone as a potential material for permeable reactive barriers (PRBs), as well as its clogging behavior, \\ are conducted under conditions that involve continuous acidic flow containing $\mathrm{Al}, \mathrm{Fe}$, and acidophilic \\ bacteria. Results show that nonhomogenous biogeochemical clogging occurred toward the outlet, \\ resulting in a $45 \%$ reduction of hydraulic conductivity at the inlet and $10 \%$ reduction at the outlet after the \\ bicarbonate buffering period. A mathematical model developed to capture the reductions in longevity is \\ presented. The model, which considers the effects of time-varying porosity, hydraulic conductivity, and \\ head at a particular point on the horizontal flow path, is used for assessing the effect of coupled clogging \\ in a calcitic porous medium.

\section{Disciplines} \\ Engineering | Science and Technology Studies

\section{Publication Details} \\ Indraratna, B., Samarakoon Jayasekara Mudiyanselage, S., Rowe, R., Thamwattana, N. \& Ribeiro Heitor, A. \\ (2020). Biogeochemical Clogging of Permeable Reactive Barriers in Acid-Sulfate Soil Floodplain. Journal \\ of Geotechnical and Geoenvironmental Engineering, 146 (5),
}




\title{
Bio-Geo-Chemical Clogging of Permeable Reactive Barriers in Acid Sulphate Soil Floodplain
}

\author{
Buddhima Indraratna PhD, FTSE, FIEAust, FASCE, FGS, CEng, CPEng \\ Distinguished Professor and Research Director, Centre for Geomechanics and Railway Engineering, \\ University of Wollongong, Wollongong, NSW 2500, Australia. E-mail: indra@uow.edu.au
}

Subhani Kanchanamala Medawela PhD candidate

Centre for Geomechanics and Railway Engineering, University of Wollongong, Wollongong, NSW 2500, Australia. E-mail: skmsj997@uowmail.edu.au

R. Kerry Rowe PhD, DEng, DSc(hc), FRS, NAE, FREng, FRSC, FCAE, FEIC, FASCE, FIE(Aust), FCSCE, PEng, CPEng

Professor and Canada Research Chair in Geotechnical and Geoenvironmental Engineering, GeoEngineering Centre at Queen's-RMC, Dept. of Civil Engineering, Queen's Univ., Kingston, ON, Canada K7L 3N6.E-mail: kerry@civil.queensu.ca

\section{Natalie Thamwattana $\mathrm{PhD}$}

Professor, School of Mathematical and Physical Sciences, University of Newcastle, University Drive, Callaghan, NSW 2308, Australia. E-mail: natalie.thamwattana@newcastle.edu.au

Ana Heitor PhD, MIEAust,

Senior Lecturer, Centre for Geomechanics and Railway Engineering, University of Wollongong, Wollongong, NSW 2500, Australia. E-mail: aheitor@uow.edu.au 


\begin{abstract}
Column experiments that investigate the use of calcitic limestone as a potential PRB reactive material as well as its clogging behaviour are investigated under conditions that involve continuous acidic flow with water containing $\mathrm{Al}$, Fe and acidophilic bacteria. Results show that non-homogenous bio-geochemical clogging occurred towards the outlet resulting in a $45 \%$ reduction of hydraulic conductivity at the inlet, and a $10 \%$ reduction at the outlet after an effective bicarbonate buffering period. A mathematical model developed to capture the reductions in longevity is presented. The model, which considers the effects of time varying porosity, hydraulic conductivity and head at a particular point on the horizontal flow path, is used for assessing the effect of coupled clogging in a calcitic porous medium.
\end{abstract}

Key words: PRB, Acidic Groundwater, Chemical Clogging, Biological clogging 


\section{Introduction}

A Permeable Reactive Barrier (PRB) is frontier technology that can be used to neutralise groundwater acidity induced by pyrite oxidation in Acid Sulfate Soil (ASS) terrain (Benner et al. 1999; Indraratna et al. 2009; Indraratna et al. 2014a). Low lying coastal acidic belts get exposed to the atmosphere due to lowering of phreatic surface in dry seasons and upon artificial draining during the course of ground infrastructure and agricultural development. This leads to the oxidation of shallow pyrite layers $\left(\mathrm{FeS}_{2}\right)$ and the production of sulfuric acid in soil, which lowers the soil $\mathrm{pH}<3$ and increases the solubility of toxic heavy metals such as aluminium (Al) and iron (Fe) (White et al. 1997). This demands effective mechanisms for removing acid pollution because once acidic groundwater mixes with nearby water bodies the aquatic fauna and flora gets destroyed by Al toxicity. Also, the highly corrosive sulfidic components become potentially detrimental to infrastructure such as pipelines, culverts and foundations (Dent and Pons 1995). A typical PRB is a trench like subsurface treatment zone filled with a proficient reactive media (Gavaskar 1999).

Despite the competent treatment of PRBs, the subsequent armouring and clogging of the reactive granular assemblies hinder their performance and longevity. The physical, chemical, and biological clogging of this porous media is caused by the accumulation of solid particles, mineral precipitates, and bio-products respectively (Indraratna et al. 2014b). More significantly, the reactive aggregates become coated with chemical precipitates and biofilms which slowly reduce reactivity and treatability, while the concurrent accumulation of chemical and biological products within the pore space of PRB reduces its porosity and permeability (Li et al. 2005).

Although the physical and chemical clogging aspects have been examined in previous research (Li et al. 2005; Indraratna et al. 2014b; Ekolu and Bitandi 2018), the pore volume 
reduction due to microbiological effects of a PRB are yet to be analysed. In particular, bacterial activities cannot be omitted in acid sulphate soils due to the catalytic role of acidophilic bacteria in pyrite oxidation and subsequent formation of mineral precipitates, apart from the growth of microbial by-products. Therefore, predicting the longevity of PRBs in ASS terrains based only on physical and chemical clogging can be erroneous, because, the reduction in permeability and porosity is also a function of bio-clogging.

In summary, the scope of this paper covers the discussion of results from an experimental investigation and the application of a mathematical approach to evaluate the performance of a PRB composed of limestone aggregates installed in an ASS floodplain. It describes in detail the investigation of chemical and biological clogging of the granular assembly when treating the acidic groundwater flowing through the PRB, and the associated reduction of its pore volume and hydraulic conductivity over time.

\section{Reactive Material}

The treatability and reactivity of infilled material are salient features of a PRB because its ability to remove contaminants depends on the properties of the reactive media (Gibert et al. 2003; Obiri-Nyarko et al. 2014). For instance, in their batch tests Golab et al. (2006b) screened various reactive materials for treating acidic groundwater and they found that alkaline materials including lime, recycled concrete, fly ash, blast furnace slag and limestone could successfully neutralise acidic constituents up to different levels. In 2006, a pilot scale PRB was installed at Shoalhaven, NSW, Australia, to treat acidic groundwater generated in a low lying ASS floodplain with recycled concrete aggregate as the reactive material (Golab et al. 2006a). Although this inexpensive waste concrete medium taken from demolition yards removed acidity and toxicity, the rate of reactivity and extent of treatability of these 
aggregates could not be predicted accurately due to variation in ageing as well as due to change in the characteristics from one batch to another.

On this basis, calcitic limestone was selected as the preferred alkaline PRB material for acid neutralisation of groundwater in the current study. Although the use of limestone mixtures to treat acid mine drainage has been considered in the past (Gibert et al. 2003; Komnitsas et al. 2004), this study specifically deals with limestone aggregates as an effective PRB medium in acid sulfate soil floodplain. The chemical composition of limestone aggregates from a plant at Moss Vale, south of Wollongong city, is given in Table 1. The large amount of $\mathrm{CaCO}_{3}(97 \%)$ indicates its obvious potential for neutralising acidic influent. The void ratio of limestone aggregates received from the plant was 0.57 and consisted of uniformly graded gravel-sized particles (GP) (ASTM D 2487 (ASTM, 2000); Indraratna et al. 2019).

\section{METHODOLOGY}

\section{Experiment Setup}

1D column experiments were carried out in the laboratory to observe the acid neutralisation properties of limestone. Four horizontal acrylic columns $($ length $=65 \mathrm{~cm}$, internal diameter $=$ $5 \mathrm{~cm}$ ) filled with limestone aggregates (Figure 1) were used to examine horizontal flow that mimics the motion of groundwater along transects parallel to the width and orthogonal to the length of a field PRB. The preparation of these columns and reactive material, which had been crushed and sieved to obtain uniform 4-5 mm sized particles, followed Indraratna et al. (2019), albeit with some modifications to introduce acidophilic bacteria into the column.

Two main column sets were arranged such that the first set (CT1) was used to examine the effect of acid neutralising due to chemical and physical clogging only, whereas the entire apparatus was sterilised beforehand to ensure that no biotic activities could occur. Before 
filling with limestone aggregates, CT1 columns were rinsed with 70\% ethanol for sterilising, while all the glass containers used for preparing and storing synthetic groundwater were autoclaved. The second column set (CT2) was used to observe acid neutralising, the biological clogging of the limestone assembly, and the coupled effect of three clogging mechanisms. Each setup had two identical columns. One of each pair was a pressure transducer column (PTC) used to monitor variations in pore pressure along the column at 100 $\mathrm{mm}$ intervals using six pressure transducers (pressure range of $0-100 \mathrm{kPa}$ and $0.5 \%$ full scale precision). The pressure readings were used to calculate the hydraulic gradients and saturated hydraulic conductivity along one column in each pair. To avoid any disturbances on pressure measurements, the second column in each pair was used for specimen collection. The water specimens were taken from six sampling ports (SP1 to SP6) along the length of the sampling column (SC) and tested for the water quality parameters (discussed later). Identical inputs were provided to both columns in each set while maintaining the same environmental conditions. Tests were carried out under constant flow conditions $(1.2 \mathrm{ml} / \mathrm{min})$ using peristaltic pumps. The columns were divided into the five conceptual zones (Figure 1) to analyse the spacial variation of treatment.

\section{Synthetic ground water}

Synthetic groundwater (Table 2) was prepared to mimic the actual groundwater chemistry of the PRB site. This synthetic water maintained a stable input into the columns, so that the experimental evaluation was based on consistent data unlike groundwater in situ, where the water quality is subjected to time dependent changes with climate variations.

\section{Culturing Bacteria}

Acidithiobacillus ferrooxidans is a facultative bacteria that can live under either aerobic or anaerobic conditions and oxidise $\mathrm{Fe}^{2+}$, pyrite, and sulfur (Olem and Unz 1977; Nordstrom 
1982). Acidithiobacillus ferrooxidans are reported to accelerate the oxidation of dissolved $\mathrm{Fe}^{2+}$ ions by five to six orders of magnitude, especially in anaerobic environments (Singer and Stumm 1970), and rapidly regenerate ferric ions $\left(\mathrm{Fe}^{3+}\right)$ in the system compared to the chemical oxidation rate of $\mathrm{Fe}^{2+}$ driven by atmospheric or dissloved oxygen (Arkesteyn 1980, Nordstrom 1982; Rawlings 2002) . These iron oxidising bacteria in the pyritic soil can enter the PRB with groundwater and grow inside the PRB due to the continous supply of nutriants from pollutants, mainly $\mathrm{Fe}^{2+}$. Thus, biologically catalysed $\mathrm{Fe}^{2+}$ oxidation occurs in the PRB according to Equation 1.

$\mathrm{Fe}_{(a q)}^{2+}+\frac{1}{4} \mathrm{O}_{2(a q)}+\mathrm{H}_{(a q)}^{+} \stackrel{\text { Bacteria }}{\longrightarrow} \mathrm{Fe}_{(a q)}^{3+}+\frac{1}{2} \mathrm{H}_{2} \mathrm{O}$

The diversity profile analysis and nucleic acid extraction conducted with the help of Australian Genome Research Facility (AGRF) confirmed the presence of bacteria at the PRB site in Shoalhaven. Figure 2 shows the level and presence of bacteria in the soil at different depths where considerable biotic activity, exacerbated by high organic content, occurs at shallow depths.

To encourage specific metabolic types of this iron related bacteria group, the basic culture media was prepared with $0.4 \mathrm{~g} / \mathrm{L} \mathrm{K}_{2} \mathrm{HPO}_{4}, 0.4 \mathrm{~g} / \mathrm{L} \mathrm{MgSO}_{4} .7 \mathrm{H}_{2} \mathrm{O}, 0.4 \mathrm{~g} / \mathrm{L}\left(\mathrm{NH}_{4}\right)_{2} \mathrm{SO}_{4}$ (Tuovinen and Kelly 1973). The $\mathrm{pH}$ of the medium was adjusted to 1.9 using sulfuric acid and then the media was autoclaved, and $5 \mathrm{~g}$ of soil taken from $0-1.5 \mathrm{~m}$ depth of the site was added aseptically to each flask. After adding $5 \mathrm{~g} / \mathrm{L} \mathrm{FeSO}_{4} .7 \mathrm{H}_{2} \mathrm{O}$ and $1 \mathrm{~g} / \mathrm{L}$ pyrite, the flasks were incubated in a shaker (Bioline incubator shaker-8500) at $32^{\circ} \mathrm{C}$ at a speed of $150 \mathrm{rpm}$. The growth of bacteria cells in each flask over time was observed with a microscope. When the batch cultures reached its exponential growth phase, numerous subcultures were prepared from the original culture to formulate the final bacterial solution. $1 \mathrm{~L}$ from the sub-cultures and $4 \mathrm{~L}$ of fresh media was then added to make a $5 \mathrm{~L}$ bacterial solution. This solution was 
kept in a rotary shaker until the cell number increased beyond $10^{7}$ cells $/ \mathrm{cm}^{3}$, after which it was used to inoculate the two columns in CT2. The samples taken from the final bacterial solution were tested again in AGRF for diversity profile analysis and to confirm the presence of iron oxidising bacteria. This procedure was then repeated throughout the column test to maintain a continuous supply of bacteria in to the columns.

\section{Column Test Procedure}

Before pumping acidic groundwater, the limestone columns were rinsed with 5-6 pore volumes of deionised water. The initial void volume of the columns (known as the pore volume, PV) of $0.678 \mathrm{~L}$ was calculated based on a measurement of the weight of the columns when (i) dry limestone with air filled voids, and (ii) limestone with fully saturated voids.

The bacteria were not introduced at the beginning of the test because the acidophiles would be inactive in the initial highly alkaline environment. Growth naturally occurs within the range $1.5<\mathrm{pH}<6$ with an optimum $\mathrm{pH}$ of 2-2.5 (Nemati et al. 1998; Rawlings 2002). Thus, the CT2 columns were not inoculated with acidophilic bacteria until the $\mathrm{pH}$ at the entrance zone of the column dropped below 4.3 after around 125 PVs of flow.

Water samples were collected daily from the main outlets of all four columns. The specimens taken from the sampling ports of each SC were collected once a week. The $\mathrm{pH}$, temperature, Electrical Conductivity (EC) and Oxidation Reduction Potential (ORP) of the samples were measured immediately using a multi-parameter water quality meter, as was the bacterial concentration of effluents from CT2. A Helber counting grid and an optical microscope was used to observe the number of cells. Effluent samples were filtered and the concentration of $\mathrm{Na}^{+}, \mathrm{K}^{+}, \mathrm{Ca}^{2+}, \mathrm{Mg}^{2+}, \mathrm{Al}^{3+}$ were measured using Inductively Coupled Plasma Optical Emission Spectroscopy (ICP-OES). Ion Chromatography (IC) was used to measure the $\mathrm{SO}_{4}{ }^{2-}$ and $\mathrm{Cl}^{-}$concentrations. Pressure variations along the horizontal flow path of the columns 
were recorded using an automated data logger connected to the 12 pressure transducers ( 6 in each column).

\section{RESULTS AND DISCUSSION}

\section{Zonal variations of acid neutralising and metal removal}

Figures $3 \mathrm{a}$ and $\mathrm{b}$ show the temporal variations of dissolved $\mathrm{Ca}$ concentration in water samples taken from SP1 to SP6. When highly acidic groundwater reacts with fresh limestone in zone 1, Ca minerals are rapidly dissolved elevating the alkalinity by releasing $\mathrm{HCO}_{3}{ }^{-}$and $\mathrm{OH}^{-}$ (Appendix1, Table A.2), and excessive acidity of water is then neutralised to some extent before entering zone 2. At the inlet, problematic ions are also partially removed from water by the formation of $\mathrm{Al}$ and $\mathrm{Fe}$ oxides and hydroxides. It is expected that armouring and precipitate formation have begun at this acid front causing a gradual reduction of $\mathrm{Ca}$ dissolution starting at 200PV in CT1 and at 150PV at CT2. In CT2, alkalinity depletion began earlier, because, $\mathrm{Fe}^{2+}$ oxidation was now accelerated by bacteria and, hence, more $\mathrm{Fe}^{3+}$ was available to form more insoluble $\mathrm{Fe}(\mathrm{OH})_{3}$, and this would be expected to cause faster armouring and clogging, thereby effecting rapid reduction of reactivity. Effluent $\mathrm{pH}$ of each zone slowly decreased with the depletion of reactivity (Figures $4 \mathrm{a}$ to $4 \mathrm{f}$ ). Removal of excessive $\mathrm{Fe}$ and $\mathrm{Al}$ from zonel to zone 5 is shown in Figure 4. Bacterial inoculation at $125 \mathrm{PV}$ was a key factor in maintaining the differences of $\mathrm{pH}$ profiles and metal removal between zones in $\mathrm{CT} 1$ and $\mathrm{CT} 2$. Although $\mathrm{Ca}$ dissolution in zone 1 was highest before armouring of that area, the Ca concentration in zone 2 exceeded that in zone 1 after 200PV in CT1 and 150PV in CT2 (Figure 3). It is because the partially treated effluent entering zone 2 was less acidic than when in zone 1, hence, the limestone gravel in this area was exposed to less acidity and less heavy metal contamination than in zone 1 . The evidence supporting this contention includes the higher $\mathrm{pH}$ and lower dissolved ion concentrations in zone 2 (Figure 
4b) than in zone 1(Figure 4a). This same treatment pattern continued from zone to zone between the column inlet and outlet, and as a consequence zone 5 experienced less acidity and metal pollution than any upgradient zones, and this resulted in the lowest alkalinity depletion at the outlet.

The $\mathrm{Fe}^{2+}$ concentration in $\mathrm{CT} 2$ was lesser than in $\mathrm{CT} 1$ because of the rapid microbial oxidation of $\mathrm{Fe}^{2+}$ in to $\mathrm{Fe}^{3+}$. Thus, after precipitating the majority of $\mathrm{Fe}^{3+}$, there should be a lower level of dissolved total $\mathrm{Fe}\left(\mathrm{Fe}^{2+}\right.$ and $\left.\mathrm{Fe}^{3+}\right)$ in the $\mathrm{CT} 2$ effluent than in CT1. For instance, the total Fe concentration in CT2-SP1 (Figure 4a) was smaller than that at CT1-SP1 until it reached 450PV. However, when the $\mathrm{pH}$ of CT2-zone 1 dropped below 3, it was expected that iron minerals would be re-dissolved, as it is the buffering point of $\mathrm{Fe}(\mathrm{OH})_{3}$ (Johnson et al. 2000). Nevertheless, the CT1-zone 1 did not reach the Fe oxy/hydroxide buffering at the same time and the iron precipitates in CT1 did not re-dissolve; therefore, after $450 \mathrm{PV}$, it may be inferred that the dissolved Fe concentration in CT2 is higher due to redissolution. Variation of total Fe concentration in the remaining zones were also similar, but the time of re-dissolution of a particular zone always occurred after its previous adjacent zone. The formation of $\mathrm{Al}(\mathrm{OH})_{3}$ also became weaker in $\mathrm{CT} 2$ because, accelerated particle coating results in $\mathrm{Al}^{3+}$ ions to remain in the solution without removal by precipitation. Thus, as shown in Figures 4a-4f, the dissolved $\mathrm{Al}^{3+}$ concentration in CT2 seems to be always higher. Furthermore, past studies also indicate that $\mathrm{Al}(\mathrm{OH})_{3}$ re-dissolves when it reaches its buffering point ( $\mathrm{pH} \sim 4$ ) (Jurjovec et al. 2002; Blowes et al. 2003), and this may be the reason for abrupt increase in dissolved $\mathrm{Al}$ at 330PV in CT1 and at $204 \mathrm{PV}$ in CT2 at the inlet (SP1).

\section{Characteristics of effluent}

Variations in the $\mathrm{pH}, \mathrm{ORP}$, and dissolved concentration of major pollutants $\left(\mathrm{Al}^{3+}\right.$ and $\left.\mathrm{Fe}^{3+}\right)$ in the column effluent are plotted against the dimensionless time (i.e., PV) in Figures 5. 
Initally, when the columns were flushed with deionised water $(\mathrm{pH}=7)$ before introducing synthetic acidic water as the influent, the efluent reached a $\mathrm{pH}$ of 8 with the dissolution of minor amounts of $\mathrm{CaCO}_{3}$ in initially deionised water. The initial ORP in the column effluents was $120 \mathrm{mV}$, which indicated weak oxidising conditons. After the synthetic groundwater was pumped in, the $\mathrm{pH}$ of both columns dropped from 8 to 6.5 within initial $80 \mathrm{PV}$ corresponding to an increase in the ORP from $124.5 \mathrm{mv}$ to $155.4 \mathrm{mv}$, suggesting that weak oxidising conditions are dominant. As shown in Figure 5a, this the reason why subsequent plateaus are observed in both $\mathrm{pH}$ profiles.

\section{Bicarbonate Buffering}

The first $\mathrm{pH}$ plateau of $\mathrm{CT} 1$ maintained a near neutral $\mathrm{pH}$ range $(6.30<\mathrm{pH}<6.71)$ until 330 $\mathrm{PV}$, followed by a slow decrease in the $\mathrm{pH}(4.72<\mathrm{pH}<6.30)$ until $630 \mathrm{PV}$ (Figure 5a); in fact, as shown in Figure 3a, this corresponds to a gradual reduction of Ca dissolution in zone 5 from 330PV onwards. This equilibrium within the range $80<\mathrm{PV}<330 \mathrm{PV}$ could be attributed to the bicarbonate buffering by dissolution reactions (Eqs. A11-A14 in Appendix 1). It could be inferred that accelerated armouring and precipitation in CT2 resulted in a shorter bicarbonate buffering zone lasting only until the $190^{\text {th }} \mathrm{PV}(6.28<\mathrm{pH}<6.60)$ where the two $\mathrm{pH}$ profiles of $\mathrm{CT} 1$ and $\mathrm{CT} 2$ were observed to differ conspicuously. By then the $\mathrm{pH}$ had gradually decreased $(4.81<\mathrm{pH} 6.28)$ until $550^{\text {th }} \mathrm{PV}$. Conversely, the ORP within the columns was observed to increase gradually indicating that the oxidising conditions within the columns have improved. At $550 \mathrm{PV}$, the ORP in CT1was 436mv whereas in CT2 it was $504 \mathrm{mV}$ with the difference attributed to the enhanced oxidising potential provided by the acidophiles (Figure 5). At the end of the gradual reduction, the $\mathrm{pH}$ in both columns dropped sharply (Figure 5a), and this can be attributed to a total depletion of alkalinity from the columns as a result of the continuous passage of acid. 
Although the concentrations of $\mathrm{Fe}$ and $\mathrm{Al}$ were very high in influent synthetic water (140mg/L and $54 \mathrm{mg} / \mathrm{L}$ respectively), they were almost completely removed (removal of 99\% Fe and $96 \% \mathrm{Al}$ ) due to bicarbonate buffering (Figure 5a). On this basis, one may identify bicarbonate buffering as the most significant aspect of treatment by limestone aggregates, because, while maintaining a near neutral main effluent, the target contaminants can also be successfully removed.

\section{Al oxy/hydroxide buffering}

A second $\mathrm{pH}$ plateau was observed in $\mathrm{CT} 1$ effluent from 650PV to $750 \mathrm{PV}$ (Figure 5a) in contrast between 550PV - 670PV in CT2. During these periods the $\mathrm{pH}$ inside the columns remained stable in the proximity of 4 , which corresponds to the buffering point for the redissolution of Al precipitates. Blowes et al. (2003) and Jurjovec et al. (2002) reported a similar state of equilibirium while treating acid mine drainage, whereas Regmi et al. (2010) observed similar conditions when columns filled with recycled concrete aggregates were used for treating acidic water. Due to the continuous supply of acidic water, equilibrium attained by the re-dissolution of $\mathrm{Al}$ oxides and hydroxides could not continuously buffer the acidity of water, so the dissolved concentration of $\mathrm{Al}$ in the main effluent increased up to $20 \mathrm{mg} / \mathrm{L}$ shortly after the value of $\mathrm{pH}$ dropped below 4.

\section{Fe oxy/ Hydroxide buffering}

$\mathrm{Fe}(\mathrm{OH})_{3}$ appeared to redissolve once the $\mathrm{pH}$ inside the columns decreased below 3 (Figure 5a). According to Johnson et al. (2000) ferric hydroxides would maintain a $\mathrm{pH} \sim 3$ when close to the equilibrium, but the mass of $\mathrm{Fe}$ precipitates would not buffer the $\mathrm{pH}$ for an extended period, hence, the effluent $\mathrm{pH}$ could eventually reach that of the influent $(\mathrm{pH}=2.8)$. 
The concentrations of the other cations $\mathrm{Na}^{+}, \mathrm{Mg}^{2+}, \mathrm{K}^{+}$, and the anions $\mathrm{Cl}^{-}$and $\mathrm{SO}_{4}{ }^{2-}$ in the influent and effluent remained essentially constant in CT1 throughout the experiment (Figure 6a). This is a clear indication that these cations have not contributed to the formation of precipitates. The concentrations of $\mathrm{SO}_{4}{ }^{2-}, \mathrm{K}^{+}$and $\mathrm{Mg}^{2+}$ in the $\mathrm{CT} 2$ (Figure 6b) increased slightly after bacteria inoculation, probably because the culture media itself consisted of these ions.

\section{Mineralogical analysis of coated particles}

The visually discernible clogging was photographed at different stages of the column experiment (Figure 7). Early in the permeation process (i.e., after 15 PV of permeation; Figure 7a) there was no visually evident clogging of pores (i.e., no build-up of solid or quasisolid material in the pores) and armouring (i.e., no apparent deposition of precipitates coating the surface of the gravel). At 390PV (Figure 7b) the gravel in the entire inlet zone of PTC1 have already been coated by bright red and yellow precipitates, while the middle and outlet zone particles were still uncoated. In PTC2, armouring (coating of the gravel surface) had commenced at both the inlet and outlet zone, indicating accelerated clogging had been induced by the biotic inoculation. At the end of the column test, both limestone columns were completely encrusted (Figure 7c).

To quantify zonal clogging, limestone particles extracted from the inlet, the middle area, and the outlet were subjected to SEM-EDS analysis (Figures 8-10). There was a greater amount of $\mathrm{Ca}$ in fresh limestone (see Ca peak shown on the EDS plot in Figure 8a) than on the CT1 and CT2 inlet gravel with a precipitate coating (i.e. much lower Ca peaks in Figure $8 \mathrm{~b}$ and 8c). Conversely, as shown in Figure 8, $\mathrm{Fe}$ and $\mathrm{Al}$ peaks are largely absent from the fresh limestone but quite evident on the coated particles form the inlet at CT1 and CT2, demonstrating the presence of Fe precipitates, and to a lesser extent $\mathrm{Al}$ precipitates on the 
surface of the limestone aggregates. As shown in Figure 8a, the SEM images of fresh particles simply indicate the limestone surface only, whereas the images of the material at the inlet of CT1 and CT2 show sufficient encrustation of clogged material such that virtually no limestone aggregates are now visible (Figure $8 b$ and $c)$.

The maximum $\mathrm{Fe}$ and $\mathrm{Al}$ peaks occurred at the inlet (Figure $8 \mathrm{~b}$ and8c) suggesting an enhanced encrustation at the entrance relative to the middle (Figure 9) and outlet (Figure 10) . Since the intensity of armouring and clogging has decreased towards the outlet, the respective Ca peaks have increased and the $\mathrm{Fe}$ and $\mathrm{Al}$ peaks decreased along the columns (Figures 9 and 10). Furthermore, as shown in Figures $8 \mathrm{~b}$ and $\mathrm{c}$, the coating of CT1 inlet appears to be less dense than the CT2 inlet particles. . The Fe and Al peaks obtained for the column inlet with coupled clogging (i.e. CT2) were higher, and the Ca peaks were lower than the column inlet with only chemical clogging (CT1), verifying that inlet clogging was quantitatively higher in CT2.

\section{Growth of Bacteria in CT2}

The bacterial cell density in CT2 and redox potential along the column both increased as the PVs increased (Figures 11a and b) although after 450-600PV the bacterial cell density plateaued and then decreased somewhat for SP1- SP4 (Figure 11a). The cell density of influent bacterial solution was always maintained within the range of $7 \times 10^{7}$ cells $/ \mathrm{cm}^{3}$ to $2.5 \times 10^{8}$ cells/ $\mathrm{cm}^{3}$, with the $\mathrm{pH}$ around 2 . However, the $\mathrm{pH}$ of CT2- zone 1 was almost 4.3 when the limestone assembly was inoculated at 125PV. Therefore, once the bacterial culture entered the column, the cells suddenly encountered a higher $\mathrm{pH}$ than in the original bacteria solution, and this condition caused a lag in cell growth in all the zones (Figure 11a). The oxidising conditions near the inlet were also weak $(138.6 \mathrm{mV})$ at the time of inoculation (Figure 11b). The number of bacterial cells in SP1 effluent was increased gradually from 
$125 \mathrm{PV}$ to $215 \mathrm{PV}$, until the $\mathrm{pH}$ of the inlet zone dropped below 3.5 at $215 \mathrm{PV}$ (Figure $4 \mathrm{a}$ ). After this decrease in $\mathrm{pH}$, the cell count increased rapidly until 550PV and then stabilised at a peak around 700PV. Cell growth at inlet was faster than the end zone due to the greater nutrient supply (i.e., more $\mathrm{Fe}^{2+}$ ) and a lower $\mathrm{pH}$. Peak cell density in other growth curves were observed at different PVs when the $\mathrm{pH}$ of the respective zone dropped below 2, which would have been the preferred acidity for this particular acidophile (Rawlings 2002).

During the growth phase, the biotic activities in the granular media increased the oxidising properties within the column, and this was indicated by an increase in the redox from 301.3 $\mathrm{mV}$ to $620.4 \mathrm{mV}$ at the entrance (Figure $11 \mathrm{~b}$ ). ORP in the remaining zones also increased with the growth of bacteria. Contrary to the above behaviour, when there was a considerable increase of acidity in zones 1 and 2, as indicated by $\mathrm{pH}$ decreasing to below 2 at around $760 \mathrm{PV}$ and 780PV respectively (Figures $4 \mathrm{a}$ and $\mathrm{b}$ ), the bacteria could have experienced a state of decay (Figure 11a). Since the column experiment was halted before the $\mathrm{pH}$ of zones 3, 4 and 5 decreased below 2, the decaying phase of these growth curves could not be captured well in Figure 11a.

\section{Reduction in hydraulic conductivity}

After obtaining the variations in pore pressure along the length of the columns, the hydraulic conductivities were calculated based on Darcy`s law. Even though a constant input rate was maintained $(1.2 \mathrm{~mL} / \mathrm{min})$ at the inlet, outlet flow rate fluctuations were observed throughout the test due to occlusion, but maintained within the range of $0.96-1.23 \mathrm{~mL} / \mathrm{min}$. Thus, a constant flow rate was assumed along the column $(1.2 \mathrm{~mL} / \mathrm{min}$ indicated by peristaltic pump $)$ for hydraulic conductivity calculations. The normalised hydraulic conductivity (i.e., the ratio between hydraulic conductivity at time t, and the initial hydraulic conductivity) decreased with both position along the column and with time (PV) for both CT1 and CT2 (Figure 12). 
At the end of the test, the hydraulic conductivity reduction was $60 \%$ for the CT1 inlet zone and $80 \%$ for CT2. The difference can be attributed to the elevated reduction in porosity caused by faster mineral fouling and the accumulation of biomass in CT2. However, of major concern is the point at which the almost neutral $\mathrm{pH}$ of the column effluent is maintained within the bicarbonate buffering zone. The hydraulic conductivity of inlet at the end of bicarbonate buffering decreased by $45 \%$ in both columns (at 400PV in CT1 and at 300PV in CT2), but it was only about $10 \%$ at the outlet (Figure 12). A notable drop of $K / K_{0}$ was observed starting at $720 \mathrm{PV}$ in $\mathrm{CT} 1$ and $685 \mathrm{PV}$ in $\mathrm{CT} 2$. After these particular PVs, pH of the effluent decreased to below 4 (Figure 5), and the capability of Al and Fe removal was considerably reduced. These observations indicate the considerable depletion of treatability of limestone at the column inlet due to physical, chemical and biological clogging, when normalised hydraulic conductivity $\left(K / K_{0}\right)=0.35$. In reality, partial replacement of granular media (at the inlet) may be required with time once the permeability drops below the threshold value.

\section{MATHEMATICAL MODELLING}

\section{Effect of bacteria growth on porosity reduction}

Biological clogging mechanisms can be categorised into three main conceptual models, namely, (i) strictly macroscopic, (ii) discrete micro-colony, and (iii) continuous biofilm (Baveye and Valocchi 1989). In the strictly macroscopic model, bacteria are considered to be attached to the solid particles and grow in isolated groups (Clement et al. 1996). The discrete micro-colony model assumes that micro-organisms grow in micro-colonies (patchy biofilms) attached to the aggregates where the growth of biomass is representative of the increased number of micro-colonies (Molz et al.1986). Thirdly, the biofilm model postulates that the surface of porous media is covered by a continuous film of biomass (Taylor and Jaffé 1990). 
It has been reported that the growth of At. Ferrooxidans on particles usually begins with cells attach themselves to the surfaces, and these cells multiply until the surface is completely covered (McGoran et al. 1969; MacDonald and Clark 1970). By following a macroscopic approach, pore morphology can be analysed without an individual visualisation of each pore, whereas microbial activity in the entire porous media can be analysed in relation to the macroscopic properties of the porous media, such as porosity and permeability (ChenCharpentier 1999). Several analytical solutions have been used in the past to evaluate the properties of porous media affected by macroscopic microbial growth (Baveye and Valocchi 1989; Clement et al. 1996). In those approaches, the average biomass concentrations are considered instead of assuming a specific micro-scale growth pattern, and even though the growth of biomass and the consumption of nutrients exists in aqueous and solid phases, it is assumed that changes in the properties of porous media are only provoked by the accumulation of solid phase biomass. Based on the above assumptions, in this study the reduction in porosity due to macroscopic growth of iron oxidising bacteria in a limestone granular assembly is estimated by (see Appendix A for details),

$n_{t_{b}}=\left(\frac{\mathrm{X}_{\mathrm{s}}}{\rho_{c}}\right)$

where $\quad \mathrm{X}_{\mathrm{S}}=\frac{X_{0} e^{k_{c} t}}{1-\frac{X_{0}}{X_{\infty}}\left(1-e^{k_{c} t}\right)}$

In the above, $n_{t_{b}}$ is the reduction in porosity due to biomass growth, $X_{s}$ is the solid phase concentration of bacterial cells $\left[\mathrm{ML}^{-3}\right]$, and $\rho_{c}$ is the solid phase biomass density $\left[\mathrm{ML}^{-3}\right]$.

The concentrations of bacterial cells has been estimated using a logistic approach (Equation 3) developed based on of Monod kinetics (Monod 1949; Shulter and Kargi 2000). $X_{0}$ is the initial bacterial cell concentration $\left[\mathrm{ML}^{-3}\right], X_{\infty}$ is the maximum bacterial cell concentration $\left[\mathrm{ML}^{-3}\right], k_{c}$ is the carrying capacity coefficient $\left[\mathrm{T}^{-1}\right]$, and $t$ is time $[\mathrm{T}]$. 
Although the cell growth in the column at time $t$ is calculated by Equation 3, when considering a shorter time after the initial time step (i.e. at time $=t_{1}+\Delta t$ ), part of the previously calculated cell number should be reduced due to endogenous cell decay or death. However, of major interest in this study is the desire to evaluate the net reduction in volume due to cell growth, extra-cellular products, and other by-products (dead cells) that accumulate in the voids. Therefore, the loss of cell mass due to decay has not been calculated separately in the growth equation. The authors have assumed that a greater percentage of dead cellular substances inside the column would be attached to the reactive surfaces and could not be removed by water flow. Thus, the total mass at time $=t_{1}$ calculated initially has not been reduced at time $t_{1}+\Delta t$.

\section{Effect of mineral precipitation on porosity reduction}

The associated reduction in porosity due to secondary mineral precipitation is given in Equation 4 (Steefel and Lasaga 1994).

$\frac{\partial \emptyset_{k}}{\partial t}=M_{k} R_{k}$

where $\emptyset_{k}$ is the volume fraction of a mineral, $M_{k}$ is the molar volume $\left(\mathrm{m}^{3} \mathrm{~mol}^{-1}\right)$ of a mineral and $R_{k}$ is the overall reaction rate for the mineral $\left(\mathrm{molm}^{-3} \mathrm{~S}^{-1}\right)$.

The change in temporal porosity due to chemical precipitates can be then obtained by Equation 5 (Indraratna et al. 2014b):

$n_{t_{c}}=n_{0}-\sum_{k=1}^{N_{m}} M_{k} R_{k} t$

where $n_{t_{c}}$ is the reduction in porosity due to secondary mineral precipitates, $n_{0}$ is the initial porosity, $N_{m}$ is the number of minerals, and $M_{k} R_{k}$ term is continuous for a particular time step. 


\section{Bio-Geo-Chemical algorithm}

Indraratna et al. (2014b) developed an algorithm for treating acidic groundwater using recycled concrete aggregates. In the current study, a bio-geo-chemical algorithm is introduced to capture the dissolution of limestone and biologically catalysed mineral precipitation during the treatment of acidic groundwater. This algorithm consists of 12 chemical and biological reactions which are detailed in Appendix A.

The kinetics of dissolution and precipitation are assumed to follow the Transition State Theory (TST) represented by Equation 6 (Eyring 1935) and successfully used by others to evaluate the rate kinetics ( $\mathrm{Li}$ et at. 2006; Mayer et al. 2006; Indraratna et al. 2014b).

$$
r=-k_{e f f}\left(1-\frac{I A P}{K_{e q}}\right)
$$

In the above, $r$ is the reaction rate of each component $\left(\mathrm{molm}^{-3} \mathrm{~S}^{-1}\right), k_{\text {eff }}$ is the effective rate coefficient $\left(\mathrm{molm}^{-3} \mathrm{~S}^{-1}\right), K_{e q}$ is solubility constant, and IAP is the ion activity product. Effective rate constants $\left(k_{e f f}\right)$ were calibration constants of a finite difference model developed by the authors to capture flow and solute transport through porous limestone media which will numerically determine the $\mathrm{pH}$ variation and timely varied concentrations of toxic heavy metals in the column. Groundwater flow modelling software, namely, MODFLOW and RT3D were used in tandem to develop the model (to be presented in the future). Values of $k_{e f f}$ are given in Appendix A. The value of $\left(I A P / K_{e q}\right)$ can be calculated directly by PHREEQC software based on the effluent concentrations of $\mathrm{Na}^{+}, \mathrm{K}^{+}, \mathrm{Ca}^{2+}, \mathrm{Mg}^{2+}$, $\mathrm{Al}^{3+}, \mathrm{Fe}^{3+}, \mathrm{Cl}^{-}$and $\mathrm{SO}_{4}{ }^{2-}$ along with the alkalinity, $\mathrm{pH}$, and temperature (Regmi et al. 2010).

The rate of microbial oxidation of $\mathrm{Fe}^{2+}$ is assumed to follow Monod's equation as given in Equation 7 (Li et at. 2006). 
$r_{\left[F e_{(a q)}^{2+}\right]_{\text {microbial }}}=k_{\left(F e_{(a q)}^{2+}\right)}\left(\frac{\left[F e_{(a q)}^{2+}\right]}{K_{\left(F e_{(a q)}^{2+}+\right.}+\left[F e_{(a q)}^{2+}\right]}\right)\left(\frac{\left[O_{2(a q)}\right]}{K_{O_{2}}+\left[O_{2(a q)}\right]}\right)\left(\frac{\left[H^{+}\right]}{K_{H^{+}}+\left[H^{+}\right]}\right)$

where $r_{\left[\mathrm{Fe}_{(a q)}^{2+}\right]_{\text {microbial }}}$ is the rate of microbial iron oxidation $\left(\mathrm{molm}^{-3} \mathrm{~s}^{-1}\right), k_{\left(F e_{(a q)}^{2+}\right)}$ is the rate coefficient $\left(\right.$ molm $\left.^{-3} \mathrm{~s}^{-1}\right), K_{\left(F e_{(a q)}^{2+}\right)}$ is the half saturation constant for ferrous, $K_{O_{2}}$ is the half saturation constant for oxygen, $K_{H^{+}}$is the half saturation constant for hydrogen, $\left[F e_{(a q)}^{2+}\right]$, $\left[\mathrm{O}_{2(a q)}\right]$ and $\left[\mathrm{H}^{+}\right]$are concentrations of ferrous, oxygen and hydrogen, respectively. More details of the bio-geo chemical algorithm are given in Appendix A.

Total $\mathrm{Fe}^{3+}$ in the system can be divided in to several components; derived by biological oxidation of $\mathrm{Fe}^{2+}$, chemical oxidation of $\mathrm{Fe}^{2+}$, and the continuous supply of $\mathrm{Fe}^{3+}$ into the column by synthetic acidic water. In the experimental data obtained for the concentration of total $\mathrm{Fe}$ in the effluent samples, it was impossible to identify each component separately. However, in the bio-geo chemical algorithm, the different rates of biological and chemical $\mathrm{Fe}^{2+}$ oxidation $\left(\mathrm{Fe}^{3+}\right.$ generation) can be distinguished, which is useful in numerical modelling to identifying significant clogging components, i.e. reduction in porosity as explained below.

\section{Variations of hydraulic head over time}

Combining Equations $3-5$, the total reduction in porosity due to biologically catalysed mineral precipitation and the accumulation of a solid phase biomass in the porous media can be represented by,

$$
\Delta n_{t}=\left[\sum_{k=1}^{N_{m}} M_{k} R_{k} t+\left(\frac{\mathrm{X}_{\mathrm{s}}}{\rho_{c}}\right)\right]
$$

where the porosity at time $t\left(n_{t}\right)$ can be expressed by,

$n_{t}=n_{0}-\Delta n_{t}$ 
Hydraulic conductivity after $\Delta n_{t}$ reduction in porosity can be expressed using the normalised Kozeny-Carmen equation as (Li et al. 2006; Indraratna et al. 2014b):

$K=K_{0}\left[\frac{n_{0}-\Delta n_{t}}{n_{0}}\right]^{3} /\left[\frac{1-n_{0}+\Delta n_{t}}{1-n_{0}}\right]^{2}$

Transient flow through a porous media can be modelled by Equation 11 (Harbaugh 2005):

$\frac{\partial}{\partial x}\left(K_{x x} \frac{\partial h}{\partial x}\right)+\frac{\partial}{\partial y}\left(K_{y y} \frac{\partial h}{\partial x}\right)+\frac{\partial}{\partial z}\left(K_{z z} \frac{\partial h}{\partial z}\right)+W=S_{s} \frac{\partial h}{\partial t}$

In the above expressions, $K_{x x}, K_{y y}$, and $K_{z z}$ are values of hydraulic conductivity along the $x, y$, and $z$ coordinate axes, which are assumed to be parallel to the major axes of hydraulic conductivity $(\mathrm{L} / \mathrm{T}) ; h$ is the hydraulic head $(\mathrm{L}) ; W$ is the volumetric flux per unit volume representing sources and/or sinks of water, $S_{S}$ is the specific storage of the porous material $\left(\mathrm{L}^{-1}\right)$; and $t$ is time $(\mathrm{T})$.

Using the normalised Kozeny-Carmen relationship, one dimensional formulation of Equation 11 can now be solved to determine the hydraulic head at time $t$ of a point located at a distance $x$ from the inlet along the direction of groundwater flow. This solution captures the chemical precipitation and the twofold biological activity, i.e., the catalytic effect by bacteria on chemical precipitation and accumulated biomass.

The general solution to Equation 11 is considered along one-dimensional flow path in the form of:

$h(x, t)=F(x) \cdot e^{F(t)}$

where,

$F(x)=\left(C_{1} \sin C x+C_{2} \cos C x\right)$

and, 


$$
\begin{aligned}
F(t)= & \frac{-C^{2}}{B}\left(-\frac{\sum_{k=1}^{N_{m}} M_{k} R_{k} t^{2}}{2}+\frac{X_{\infty}}{\rho_{c} K_{c}} \ln \left[1-\frac{X_{0}}{X_{\infty}}\left(1-e^{k_{c} t}\right)\right]+\left(n_{o}+2\right) t-3 \ln \left[f(t)-n_{o}+1\right]+\right. \\
& \left.3 \ln \left[\frac{X_{0}}{\rho_{c}}-n_{o}+1\right]+\frac{1}{f(t)-n_{o}+1}-\frac{1}{\left(\frac{X_{0}}{\rho_{c}}-n_{o}+1\right)}\right)
\end{aligned}
$$

In the above, $\mathrm{B}$ is a constant, and,

$f(t)=\sum_{k=1}^{N_{m}} M_{k} R_{k} t+\frac{X_{0} X_{\infty} e^{k_{c} t}}{\rho_{c}\left\{X_{\infty}-X_{0}\left(1-e^{k_{c} t}\right)\right\}}$

Where $\mathrm{C}, \mathrm{C}_{1}$ and $\mathrm{C}_{2}$ are integral constants.

The step by step development of Equation 12 is described in Appendix B. To the knowledge of the authors, this is the first time an analytical solution has been developed for variations in the hydraulic head that will capture both chemical and biological clogging in a PRB. The past solution by Indraratna et al. (2014b) only included geochemical clogging in recycled concrete excluding bio-clogging effects.

Experimental variations in the head at different distances from the column inlet of CT2 are shown in Figure 13 together with the solution obtained using Equation 12. Overall, the head measured at a point increased over time while the porous medium became clogged obstructing the flow paths. The laboratory results are in good agreement with the solution obtained by the mathematical model. At the entrance zone $(\mathrm{x}=0$ and $\mathrm{x}=10 \mathrm{~cm})$, the total head increased by having clearly noticeable rest periods during which the pressure transducer readings remained nearly constant. At $325-375 \mathrm{PV}$, the total head of zone 1 was nearly constant when the calcitic porous matrix began to clog during the first $\mathrm{pH}$ plateau. The authors interpret that these stagnated readings represent clogging of the pore space adjacent to the transducer, which may result in erroneous data. Subsequently, the increase in total head agrees with the mathematical solution, thus indicating a readjustment of flow paths within the column. At $580-690 \mathrm{PV}$, although the $\mathrm{Al}$ precipitates redissolved $(\mathrm{pH} \sim 4)$, the formation of $\mathrm{Fe}(\mathrm{OH})_{3}$ continued due to the exacerbating bacteria, thus causing continuous pore blockage and another set of stagnated transducer readings at the inlet. When re-dissolution of Fe 
commenced, the flow paths altered accordingly, and again the head variation followed the general trend (Figure 13).

\section{Model Limitations}

Since clogging in final three zones was minimal, the pressure measurements were hardly affected, however, the measured head was slightly lower than the mathematically modelled head. Biomass growth was considered to be homogeneous in the authors' mathematical model, although was shown to decrease towards the outlet in the actual case, making the model conservative. In reality the calculated head should be slightly lower because clogging at the outlet $(\mathrm{x}=50 \mathrm{~cm})$ is lesser than the other zones. Moreover, the 1D flow solution represented in Equation 12 may be applicable in the field when cross-flows are neglected. In spite of the above limitations, the proposed mathematical model is encouraging to simulate bio-geochemical clogging of a PRB.

\section{Practical Implications}

A laboratory column mimics the groundwater flow along transects parallel to the width of a PRB; i.e. despite the field scale, the flow along the centreline of a PRB is ideally modelled by a 1D column. It is noteworthy that the same chemical and biological reactions occur in the laboratory and in a real-life PRB, but the bio-chemical process is often accelerated during the simulated experiments with more stringently controlled conditions (e.g., constant $\mathrm{pH}$, concentrations of ions and bacteria in the influent, accelerated flowrates, usually smaller particle sizes, and constant temperature). The appropriate time factor and the scale effect can be captured mathematically by incorporating the modified rate kinetics and dimensional analysis in the bio-geo-chemical algorithm. In particular, $k_{\text {eff }}$ of each reaction given in Appendix 1 and Table A.2 can be adjusted on the basis of field dimensions (i.e., an enlarged column) along the PRB centreline adopting the MODFLOW finite difference discretization. 
Therefore, numerically quantifying the rate kinetics applicable to the given field situation, temporal variations of porosity and hydraulic conductivity of the PRB can then be evaluated using Equations 9 and 10, which then become the crucial geo-hydraulic parameters for running RT3D (FDM approach) coupled with the output of MODFLOW.

At each time step of the numerical model, these parameters will then correspond to the critical PV at which the effluent $\mathrm{pH}$ is no longer neutral and the ability to remove toxic metals becomes considerably retarded. More significantly, at this stage, the hydraulic conductivity will begin to drop steeply, thus at this point in time one can then deduce the PRB's effective life span or longevity.

This process will be applied to a PRB with limestone aggregates which is currently being designed for construction in a site in Hunter Valley, NSW, Australia by Glencore mines to treat mine acid drainage. The authors expect the health monitoring and model validation at this site to be presented in a subsequent paper.

\section{Conclusions}

In this study, the influence of biologically catalysed mineral precipitation on the porosity and associated flow properties of a PRB was simulated using laboratory column tests. Armouring and clogging of the limestone granular assembly were predominant near the column inlet (i.e., flow entrance) and decreased towards the outlet. In other words, the line of treatment of a PRB would progress deeper in to the granular matrix in the direction of flow, when the reactivity of the aggregates near the inlet diminishes over time. At least $70 \%$ reduction in the rate of $\mathrm{Ca}$ dissolution and $80 \%$ reduction in hydraulic conductivity at the inlet of the column could be attributed to significant bio-geochemical clogging, whereas at the far outlet the corresponding values were much lower at $55 \%$ and $10 \%$, respectively. When there was no 
bacterial inoculation, only chemical clogging occurred; the resulting reduction in hydraulic conductivity at the inlet was $60 \%$, which demonstrated the importance of capturing both chemical and biological clogging when predicting the longevity of a PRB.

This study also confirmed that limestone aggregates are a suitable material for PRBs intended to treat acidic groundwater formed in an acid sulphate (pyritic) soil terrain. The most satisfactory treatment results were observed throughout the bicarbonate buffering phase, and during this period the $\mathrm{pH}$ of the column effluent became almost neutral, and the removal rate of $\mathrm{Al}$ and $\mathrm{Fe}$ toxic ions was nearly perfect at $96-99 \%$. It is important to identify the threshold point at which the effluent becomes acidic with unacceptable heavy metal concentrations, while the hydraulic conductivity of the granular assembly begins to drop substantially. In fact, these are indeed the main factors that highlight the requirement for replacing the reactive aggregates towards the end of the PRB's life-span. In the column experiments, combined biogeo-chemical clogging caused this particular limit to occur at 685PV when normalised hydraulic conductivity $\left(K / K_{0}\right)$ at the inlet began to drop below 0.35 .

A mathematical model was developed which could estimate the time-dependent reduction in porosity of the reactive porous medium and the variation of hydraulic head with distance along the flow path. The encouraging model predictions in relation to experimental data provide confidence for extending the $1 \mathrm{D}$ column simulation to real-life groundwater flow along the centreline of the PRB, by adjusting the rate kinetics to the actual scale through numerical modelling. 


\section{Data Availability Statement}

1) The following data used during the study are available online.

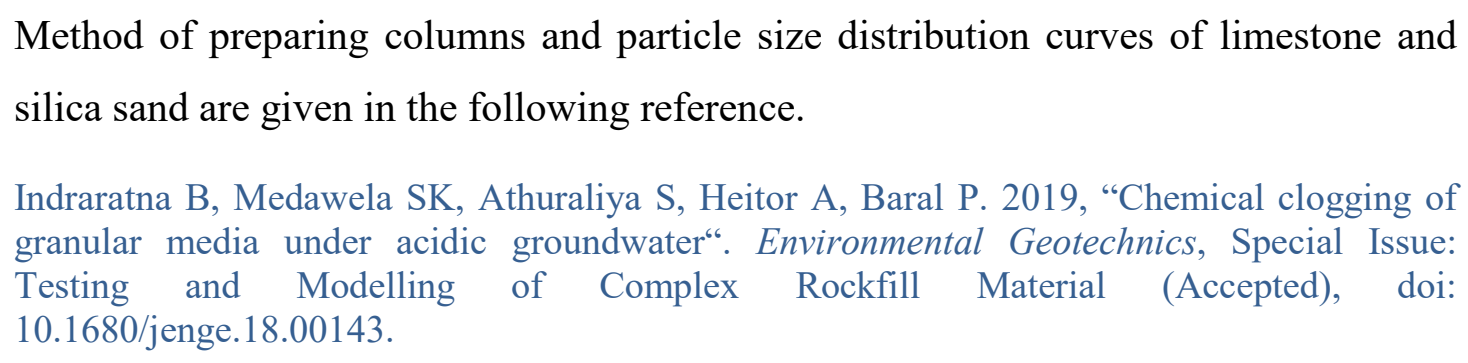

2) All other data, models, and code generated or used during the study appear in the submitted article

\section{Acknowledgement}

The authors are grateful for funding received from the Australian Research Council (ARC) during the year to support research in this area. Continuous support and assistance from industry partners is highly appreciated, with special thanks to, Glenys Lugg from Manildra Group and Paul Amidy from Glencore. The authors are thankful to Dr Helen Watling for her support in microbial experiments. Omya Australia. Ltd., is also acknowledged for their support in providing the limestone for tests. The authors would like to acknowledge the use of facilities within the UOW Electron Microscopy Centre. The efforts of UOW technical staff and more than a dozen past $\mathrm{PhD}$ and Honours thesis students' research work in the field of acid sulfate soils are gratefully acknowledged. 


\section{Appendix A: Development of bio-geo chemical algorithm}

Microbial growth rate can be expressed using Monad kinetics (Monod, 1949) as:

$$
\mu_{n e t}=\frac{1}{X} \frac{d X}{d t}
$$

Net specific growth rate $\left(\mu_{n e t}\right)$ is the difference between gross specific growth rate and $\left(\mu_{g}\right)$ and rate of loss of cell mass due to cell death $\left(k_{d}\right)$ as defined in Equation A.2.

$\mu_{n e t}=\mu_{g}-k_{d}$

In the current study, the loss of biotic cell mass due to cell death was neglected. Assuming that the majority of decaying cell mass is to remain inside column attached to the reactive matrix,

$\mu_{n e t}=\mu_{g}$

When the above kinetics are arranged in the form of a logistic equation (Shulter and Kargi, 2000), bacterial growth can be expressed in terms of carrying capacity. Thus,

$\mu_{g}=k_{c}\left(1-\frac{X}{X_{\infty}}\right)$

$\frac{d X}{d t}=k_{c} X\left(1-\frac{X}{X_{\infty}}\right)$

The integration of Equation A.5 with the boundary condition $X(0)=X_{o}$, i.e. assuming that when the bacterial solution is pumped into the column the initial microbial concentration at the column inlet is equal to the concentration in the bacterial solution, therefore cell growth can be expressed as,

$$
\mathrm{X}_{\mathrm{S}}=\frac{X_{0} e^{k_{c} t}}{1-\frac{X_{0}}{X_{\infty}}\left(1-e^{k_{c} t}\right)}
$$


By fitting the growth data of batch culture of selected bacteria strain (Figure A.1), the growth kinetics can be calculated, thus $X_{0}=7 \times 10^{7}$ cells $/ \mathrm{cm}^{3}, X_{\infty}=2.5 \times 10^{8}$ cells $/ \mathrm{cm}^{3}$ and $k_{c}=0.1272 \mathrm{~d}^{-1}$.

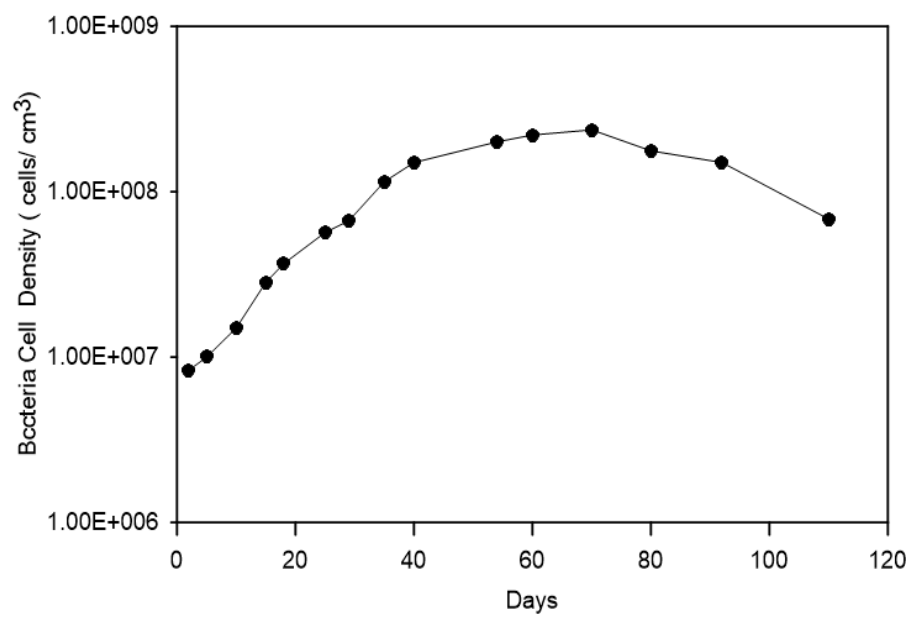

Figure A.1. Batch growth curve for iron oxidising bacteria

Effect of accumulated biomass on porosity can be written as:

$n_{t_{b}}=\left(n_{0}-\frac{\mathrm{x}_{\mathrm{s}}}{\rho_{c}}\right)$

Reduction in porosity caused by secondary mineral precipitates can then be written as:

$n_{t_{c}}=n_{0}-\sum_{k=1}^{N_{m}} M_{k} R_{k} t$

where the reaction rate of each precipitation reaction is calculated based on the transition state theory using Equation A.8.

$r=-k_{e f f}\left(1-\frac{I A P}{K_{e q}}\right)$

Effective rate constants $\left(k_{e f f}\right)$ were calibration constants of a numerical model developed by the authors to capture flow and solute transport through porous limestone media. Ground water flow modelling software, MODFLOW and RT3D were used in tandem to develop the 
numerical model (to be presented in the future). Values for $k_{\text {eff }}$ were obtained by the numerical model as shown in Table A.1.

Table A.1.Values for $k_{e f f}$ obtained by numerical modelling

\begin{tabular}{ll}
\hline Mineral & $\boldsymbol{k}_{\text {eff }}(\mathbf{m o l} / \mathbf{L s})$ \\
\hline $\mathrm{CaCO}_{3}$ & $2.434 \times 10^{-7}$ \\
$\mathrm{Al}(\mathrm{OH})_{3}$ & $3.803 \times 10^{-8}$ \\
$\mathrm{Fe}(\mathrm{OH})_{3}$ & $1.661 \times 10^{-8}$ \\
$\mathrm{Fe}(\mathrm{OOH})$ & $1.499 \times 10^{-8}$ \\
$\mathrm{Fe}_{2} \mathrm{O}_{3}$ & $2.193 \times 10^{-8}$ \\
$\mathrm{Chemical}_{3}$ Iron Oxidation & $1.004 \times 10^{-7}$ \\
Microbial Iron Oxidation & $3.651 \times 10^{-7}$ \\
\hline
\end{tabular}

By combining major dissolution and precipitation reactions, a bio-geo chemical algorithm was developed so that individual reaction rates $(r)$ could be calculated, and thus the overall reaction rate, $R_{k}$ could be evaluated.

Thus the porosity of limestone media at time $t$ is given by:

$n_{t}=n_{0}-\sum_{k=1}^{N_{m}} M_{k} R_{k} t-\left(\frac{\mathrm{X}_{\mathrm{s}}}{\rho_{c}}\right)$

\section{Bio-Geo-Chemical Algorithm}

Calcite dissolution and biologically catalysed mineral precipitation reactions are described in Table A.2. Chemical precipitation was assumed to follow the transition state theory (Equation A.9), while biotic oxidation of ferrous was explained using the Monod kinetics explained earlier.

Combining individual reaction rates described in Table A.2, the overall reactive rates $\left(R_{k}\right)$ for each species in the algorithm are listed below.

$\frac{d\left[\mathrm{Ca}^{2+}\right]}{d t}=-r_{1\left[\mathrm{Ca}^{2+}\right]}-r_{2\left[\mathrm{Ca}^{2+}\right]}-r_{3\left[\mathrm{Ca}^{2+}\right]}-r_{4\left[\mathrm{Ca}^{2+}\right]}$ 


$$
\begin{array}{ll}
\frac{d\left[A l^{3+}\right]}{d t}= & r_{1\left[A l^{3+}\right]} \\
\frac{d\left[\mathrm{Fe}^{3+}\right]}{d t}= & r_{1\left[\mathrm{Fe}^{3+}\right]}+r_{2\left[\mathrm{Fe}^{3+}\right]}+2 r_{3\left[\mathrm{Fe}^{3+}\right]}-r_{\left[F e_{(a q)}^{2+}\right]_{\text {Chemical }}}-r_{\left[F e_{(a q)}^{2+}\right]_{\text {microbial }}} \\
\frac{d\left[\mathrm{Fe}^{2+}\right]}{d t}= & 2 r_{1\left[\mathrm{Fe}^{2+}\right]}+2 r_{2\left[\mathrm{Fe}^{2+}\right]}+r_{\left[F e_{(a q)}^{2+}\right]_{\text {Chemical }}}+r_{\left[F e_{(a q)}^{3+}\right]_{\text {microbial }}}
\end{array}
$$


Table A.2. Biological and geochemical reactions occurred in columns

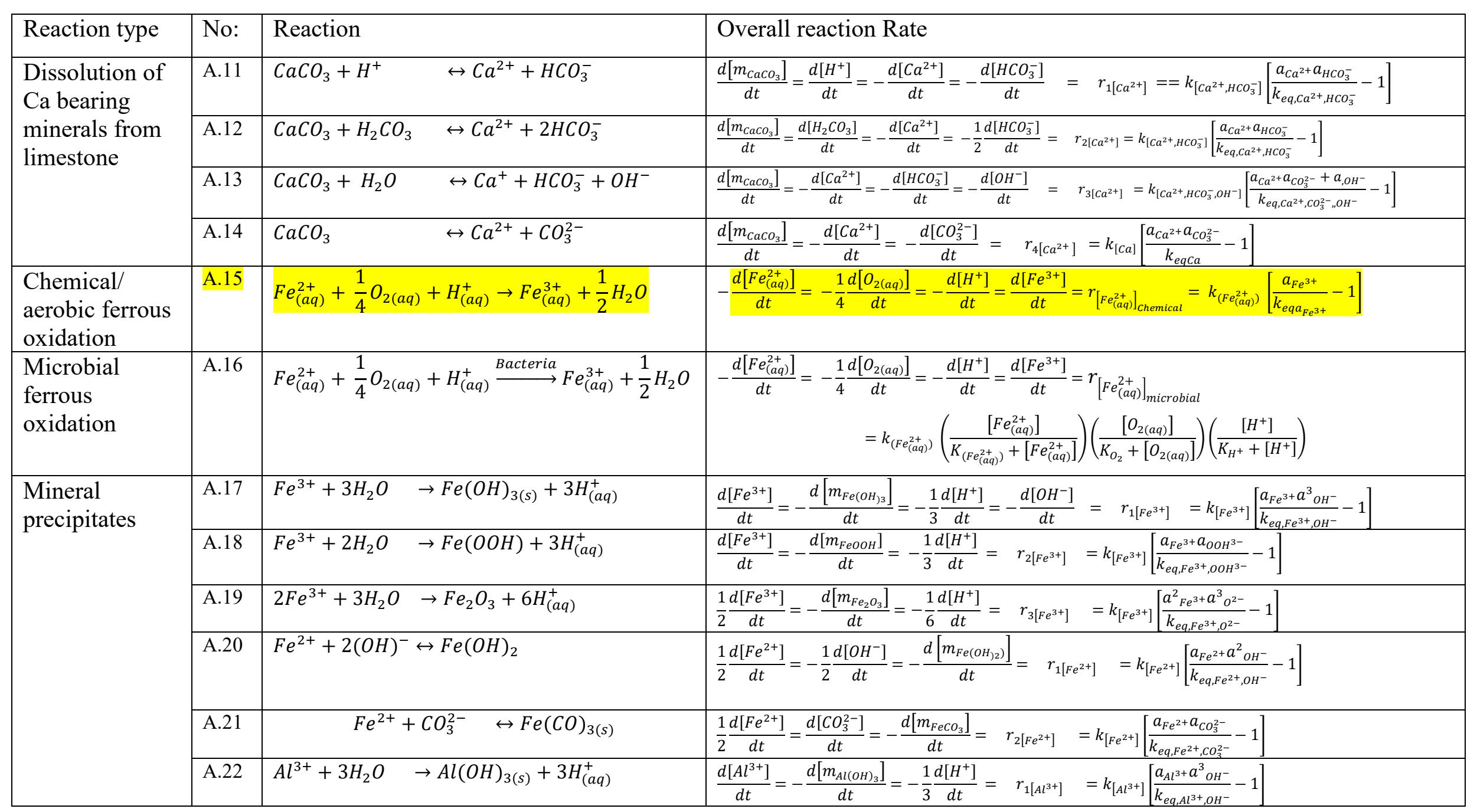




\section{Appendix B: Developing the solution for hydraulic head along the flow path}

The flow of transient groundwater in one dimension can be written as (Harbaugh 2005; Indraratna et.al. 2014b):

$\frac{\partial^{2} h}{\partial x^{2}}=\frac{S}{K b}\left(\frac{\partial h}{\partial t}\right)$

From Kozeny-Carmen equation, normalised hydraulic conductivity can be written as:

$K=K_{0}\left[\frac{n_{0}-\Delta n_{t}}{n_{0}}\right]^{3} /\left[\frac{1-n_{0}+\Delta n_{t}}{1-n_{0}}\right]^{2}$

The total reduction in porosity due to mineral precipitation and the accumulation of solid phase biomass in the porous media can be written as follows:

$\Delta n_{t}=\left[\sum_{k=1}^{N_{m}} M_{k} R_{k} t+\left(\frac{\mathrm{X}_{\mathrm{s}}}{\rho_{c}}\right)\right]=f(t)$

By substituting B.2 and B.3 to B.1,

$\frac{\partial^{2} h}{\partial x^{2}}=g(t) \cdot \frac{\partial h}{\partial t}$

where $g(t)=B \frac{\left(1-n_{0}+f(t)\right)^{2}}{\left(n_{0}-f(t)\right)^{3}}$

$f(t)=\sum_{k=1}^{N_{m}} M_{k} R_{k} t+\frac{X_{0} X_{\infty} e^{k_{c} t}}{\rho_{c}\left\{X_{\infty}-X_{0}\left(1-e^{k_{c} t}\right)\right\}}$

and, $B=\frac{S n_{0}{ }^{3}}{b K_{0}\left(1-n_{0}\right)^{2}}$, a constant.

Assuming a solution of separating the type of variable,

$$
\begin{aligned}
& h(x, t)=X(x) \cdot Y(t) \\
& \frac{\partial h}{\partial x}=Y X^{\prime} \\
& \frac{\partial^{2} h}{\partial x^{2}}=Y X^{\prime \prime} \\
& \frac{\partial h}{\partial t}=X Y^{\prime}
\end{aligned}
$$


Substituting B.9 and B.10 to B.4 yields:

$Y X^{\prime \prime}=g(t) X Y^{\prime}$

Let $-C^{2}=\frac{X^{\prime \prime}}{X}=g(t) \frac{Y^{\prime}}{Y}$

where $C$ is an arbitrary constant.

Therefore,

$\frac{X^{\prime \prime}}{X}=-C^{2}$

$-C^{2}=g(t) \frac{Y^{\prime}}{Y}$

$\int_{t_{o}}^{t} \frac{-C^{2}}{g(t)} d t=\int_{t_{o}}^{t} \frac{Y^{\prime}}{Y}$

$Y(t)=Y\left(t_{o}\right) \cdot e^{\int_{t_{o}}^{t} \frac{-C^{2}}{g(t)} d t}$

By Solving Equation B.13 gives:

$X(t)=c_{1} \operatorname{Sin}(C x)+c_{2} \operatorname{Cos}(C x)$

B.7 can now be rearranged as follows:

$h(x, t)=\left\{c_{1} \operatorname{Sin}(C x)+c_{2} \operatorname{Cos}(C x)\right\} \cdot\left(Y\left(t_{o}\right) \cdot e^{\int_{t_{o}}^{t} \frac{-C^{2}}{g(t)} d t}\right)$

Let $c_{1} Y\left(t_{o}\right)=C_{1}$ and $\quad c_{2} Y\left(t_{o}\right)=C_{2}$ and

$h(x, t)=\left\{C_{1} \operatorname{Sin}(C x)+C_{2} \operatorname{Cos}(C x)\right\} \cdot \exp \left(\int_{t_{o}}^{t} \frac{-C^{2}}{g(t)} d t\right)$ 
The values of $C, C_{1}$ and $C_{2}$ are found using the following initial conditions:

$$
\begin{aligned}
& h(0,0)=h_{1} \\
& h(l, 0)=h_{2} \\
& \frac{\partial h}{\partial t}_{(0,0)}=H
\end{aligned}
$$

Let $\int_{t_{o}}^{t} \frac{-C^{2}}{g(t)} d t=F(t)$

Thus the general solution to Equation B.1 captures the effects of chemical and biological clogging, hence:

$$
h(x, t)=F(x) \cdot e^{F(t)}
$$

In the above,

$$
\begin{aligned}
F(x)= & \left(C_{1} \sin C x+C_{2} \cos C x\right) \\
F(t)= & \frac{-C^{2}}{B}\left(-\frac{\sum_{k=1}^{N_{m}} M_{k} R_{k} t^{2}}{2}+\frac{X_{\infty}}{\rho_{c} K_{c}} \ln \left[1-\frac{X_{0}}{X_{\infty}}\left(1-e^{k_{c} t}\right)\right]+\left(n_{o}+2\right) t-3 \ln \left[f(t)-n_{o}+1\right]+\right. \\
& \left.3 \ln \left[\frac{X_{0}}{\rho_{c}}-n_{o}+1\right]+\frac{1}{f(t)-n_{o}+1}-\frac{1}{\left(\frac{X_{0}}{\rho_{c}}-n_{o}+1\right)}\right)
\end{aligned}
$$




\section{List of Notation}

$\emptyset_{k}=$ Volume fraction of mineral

$\mu_{g}=$ Gross specific growth rate $\left[\mathrm{T}^{-1}\right]$

$\mu_{\text {net }}=$ Net specific growth rate $\left[\mathrm{T}^{-1}\right]$

$\rho_{c}=$ Solid phase biomass density $\left[\mathrm{ML}^{-3}\right]$

$\Delta n_{t}=$ Porosity reduction at time $\Delta \mathrm{t}$

$b=$ Aquifer thickness [L]

$C, C_{1}, C_{2}=$ Integral Constants

$h=$ Hydraulic head $[\mathrm{L}]$

$t=$ Time

$K=$ Hydraulic conductivity at time $\mathrm{t}\left[\mathrm{LT}^{-1}\right]$

$k_{c}=$ Carrying Capacity Coefficient $\left[\mathrm{T}^{-1}\right]$

$k_{d}=$ Endogenous decay coefficient $\left[\mathrm{T}^{-1}\right]$

$k_{e f f}=$ Effective rate coefficient $\left(\mathrm{molm}^{-3} \mathrm{~s}^{-1}\right)$

$K_{e q}=$ Solubility Constant for the reaction

$K_{o}=$ Initial hydraulic conductivity $\left[\mathrm{LT}^{-1}\right]$

$K_{\left(\mathrm{Fe}_{(a q)}^{2+}\right)}=$ Half saturation constant for ferrous $\left[\mathrm{ML}^{-1}\right]$

$K_{O_{2}}=$ Half saturation constant for oxygen $\left[\mathrm{ML}^{-1}\right]$

$K_{H^{+}}=$Half saturation constant for hydrogen [ $\left.\mathrm{ML}^{-1}\right]$

$M_{k}=$ Mineral molar volume $\left(\mathrm{m}^{3} \mathrm{~mol}^{-1}\right)$

$N_{m}=$ Number of minerals

$n_{0}=$ Initial porosity

$n_{t_{b}}=$ Porosity reduction due to biomass growth

$n_{t_{c}}=$ Porosity reduction due to chemical precipitates

$r=$ Reaction rate of each component $\left(\mathrm{molm}^{-3} \mathrm{~s}^{-1}\right)$

$r_{\left[\mathrm{Fe}_{(a q)}^{2+}\right]_{\text {microbial }}}=$ Rate of microbial iron oxidation $\left(\mathrm{molm}^{-3} \mathrm{~s}^{-1}\right)$

$R_{k}=$ Overall reaction rate for the mineral $\left(\mathrm{molm}^{-3} \mathrm{~s}^{-1}\right)$

$S=$ Storage coefficient

$X_{0}=$ Initial bacterial cell concertation $\left[\mathrm{ML}^{-1}\right]$

$X_{S}=$ Solid phase bacterial cell concentration $\left[\mathrm{ML}^{-1}\right]$

$X_{\infty}=$ Maximum bacterial cell concentration $\left[\mathrm{ML}^{-1}\right]$ 


\section{List of Tables}

Table 1. Chemical analysis of fresh limestone

Table 2. Chemistry of the influent water for column experiments

Table A.1. Values for $k_{e f f}$ obtained by numerical modelling

Table A.2. Biological and geochemical reactions occurred in columns

Table 1. Chemical analysis of fresh limestone

\begin{tabular}{llll}
\hline \multicolumn{2}{c}{ Mineral composition } & \multicolumn{2}{l}{ Trace element composition } \\
\hline Mineral & Percentage (\%) & Element & Concentration(mg/kg) \\
\hline $\mathrm{CaCO}_{3}$ & 97.212 & Arsenic & 0.77 \\
$\mathrm{MgCO}_{3}$ & 1.221 & Boron & 0.19 \\
$\mathrm{SiO}_{2}$ & 0.579 & Cadmium & 0.11 \\
$\mathrm{Al}_{2} \mathrm{O}_{3}$ & 0.207 & Chromium & 0.76 \\
$\mathrm{Fe}_{2} \mathrm{O}_{3}$ & 0.149 & Copper & 0.41 \\
& & Lead & 1.6 \\
& & Mercury & $<0.01$ \\
& & Molybdenum & 0.07 \\
& & Nickel & 0.1 \\
& & Selenium & 0.07 \\
& & Tin & $<0.02$ \\
& & Zinc & 2.8 \\
\hline
\end{tabular}

Table 2. Chemistry of the influent water for column

\begin{tabular}{lll}
\hline Parameter & Unit & Values \\
\hline $\mathrm{pH}$ & & 2.8 \\
$\mathrm{ORP}$ & $\mathrm{mV}$ & 610 \\
Acidity equivalent to $\mathrm{CaCO}_{3}$ & $\mathrm{mmol} \mathrm{eq} / \mathrm{L}$ & 6.45 \\
$\mathrm{Na}^{+}$ & $\mathrm{mg} / \mathrm{L}$ & 504.2 \\
$\mathrm{~K}^{+}$ & $\mathrm{mg} / \mathrm{L}$ & 50.1 \\
$\mathrm{Ca}^{2+}$ & $\mathrm{mg} / \mathrm{L}$ & 152.2 \\
$\mathrm{Mg}^{2+}$ & $\mathrm{mg} / \mathrm{L}$ & 118.0 \\
$\mathrm{Al}^{3+}$ & $\mathrm{mg} / \mathrm{L}$ & 54.0 \\
$\mathrm{Fe}^{3+}$ & $\mathrm{mg} / \mathrm{L}$ & 49 \\
$\mathrm{Fe}^{3+}$ & $\mathrm{mg} / \mathrm{L}$ & 91 \\
$\mathrm{Cl}^{-}$ & $\mathrm{mg} / \mathrm{L}$ & 849.0 \\
$\mathrm{SO}_{4}{ }^{2-}$ & $\mathrm{mg} / \mathrm{L}$ & 1450.0 \\
\hline
\end{tabular}




\section{List of Figures}

Figure 1. Laboratory column experiment setup (SC: Sampling Column, PTC: Pressure Transducer column)

Figure 2. Presence of iron oxidising bacteria and organic content at different depths of Shoalhaven acid sulfate soil

Figure 3. Variations in the effluent parameters with time a) $\mathrm{pH}$, dissolved Total $\mathrm{Fe}$ and $\mathrm{Al}^{3+}$ b) Oxidation Reduction Potential (ORP)

Figure 4. Variations of $\mathrm{Ca}^{2+}$ along the length of the columns a) CT1 b) CT2

Figure 5. Temporal variations of $\mathrm{pH}$ and dissolved Total $\mathrm{Fe}$ and $\mathrm{Al}^{3+}$ along the length of the columns

Figure 6. Concentrations of other ions dissolved in the column effluent: a) CT1 b) CT2

Figure 7. Formation of $\mathrm{Fe}$ and $\mathrm{Al}$ precipitates along the columns with time

Figure 8.Energy-dispersive X-ray spectroscopy (EDS) analysis of limestone (a) Fresh limestone (b) Particles extracted from CT1 inlet (c) Particles extracted from CT2 inlet

Figure 9. Energy-dispersive X-ray spectroscopy (EDS) analysis of extracted coated particles from middle area of the column (a) CT1 (b) CT2

Figure 10. Energy-dispersive X-ray spectroscopy (EDS) analysis of extracted coated particles from outlet of columns (a) CT1 (b) CT2Figure 11.

Figure 11. (a) Bacteria cell density of sampling effluents along CT2 (b) ORP variation in CT2

Figure 12. Variations of normalised hydraulic conductivity along the length of CT1 and CT2

Figure 13. Variations of hydraulic head at different distances from CT2 inlet

Figure A.1. Batch growth curve for iron oxidising bacteria 




Figure 1. Laboratory column experiment setup (SC: Sampling Column, PTC: Pressure Transducer column) 


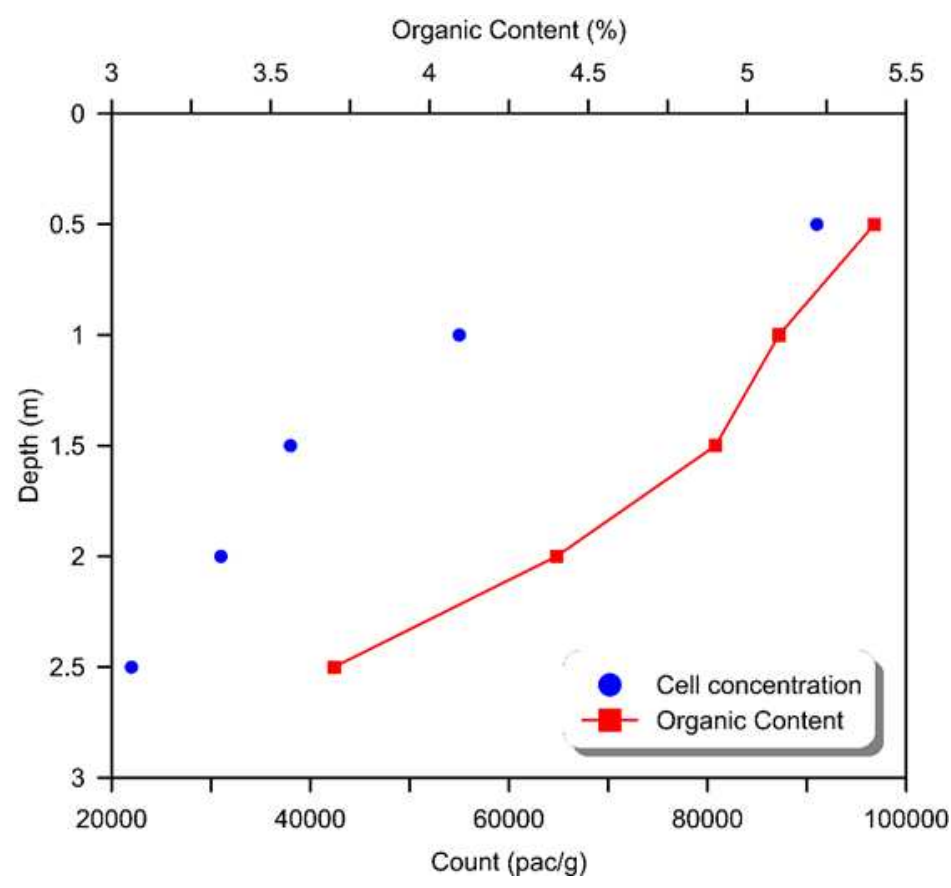

Figure 2. Presence of iron oxidising bacteria and organic content at different depths of Shoalhaven acid sulfate soil 

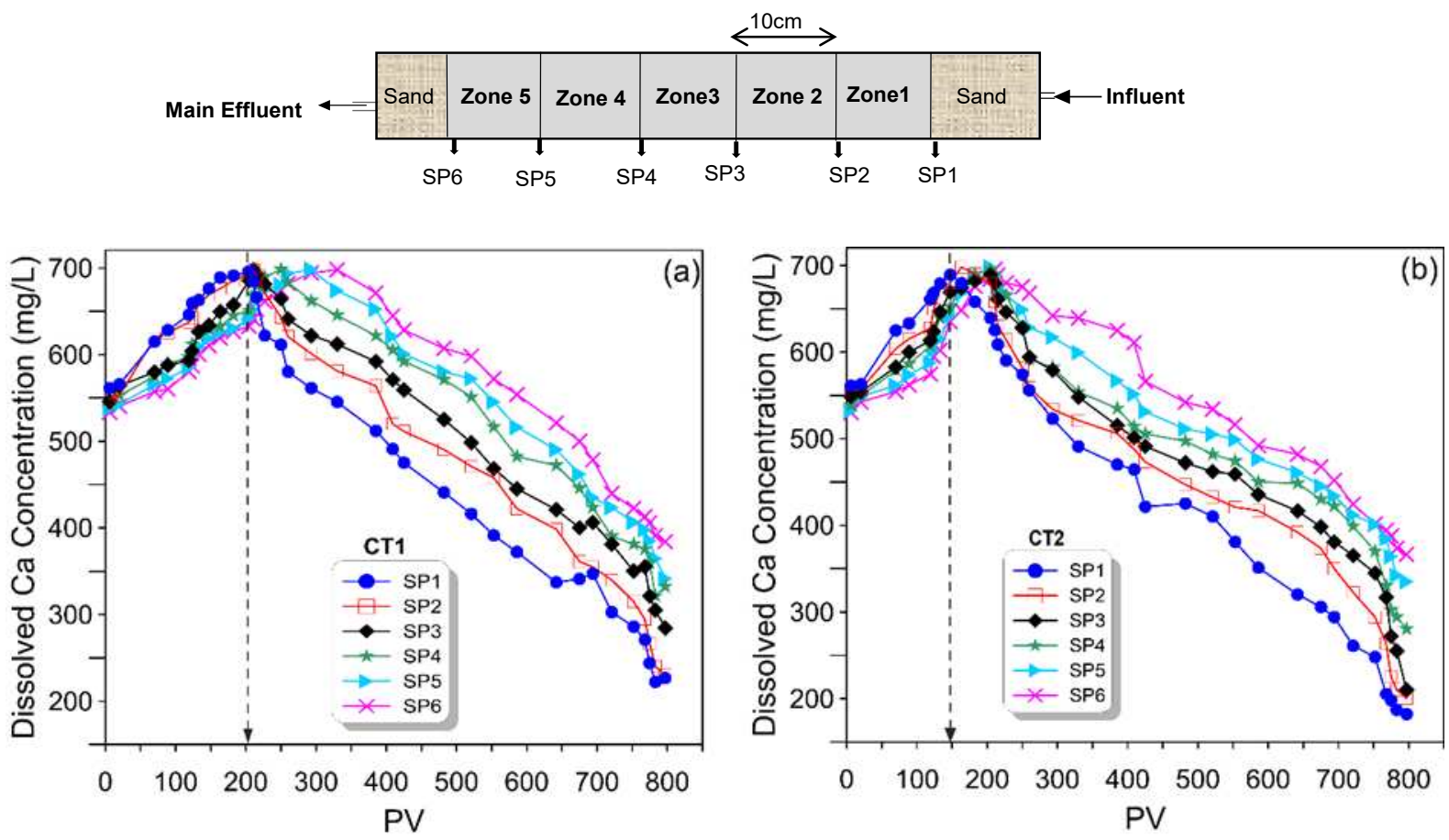

Figure 3. Variations of $\mathrm{Ca}^{2+}$ along the length of the columns a) CT1 b) CT2 

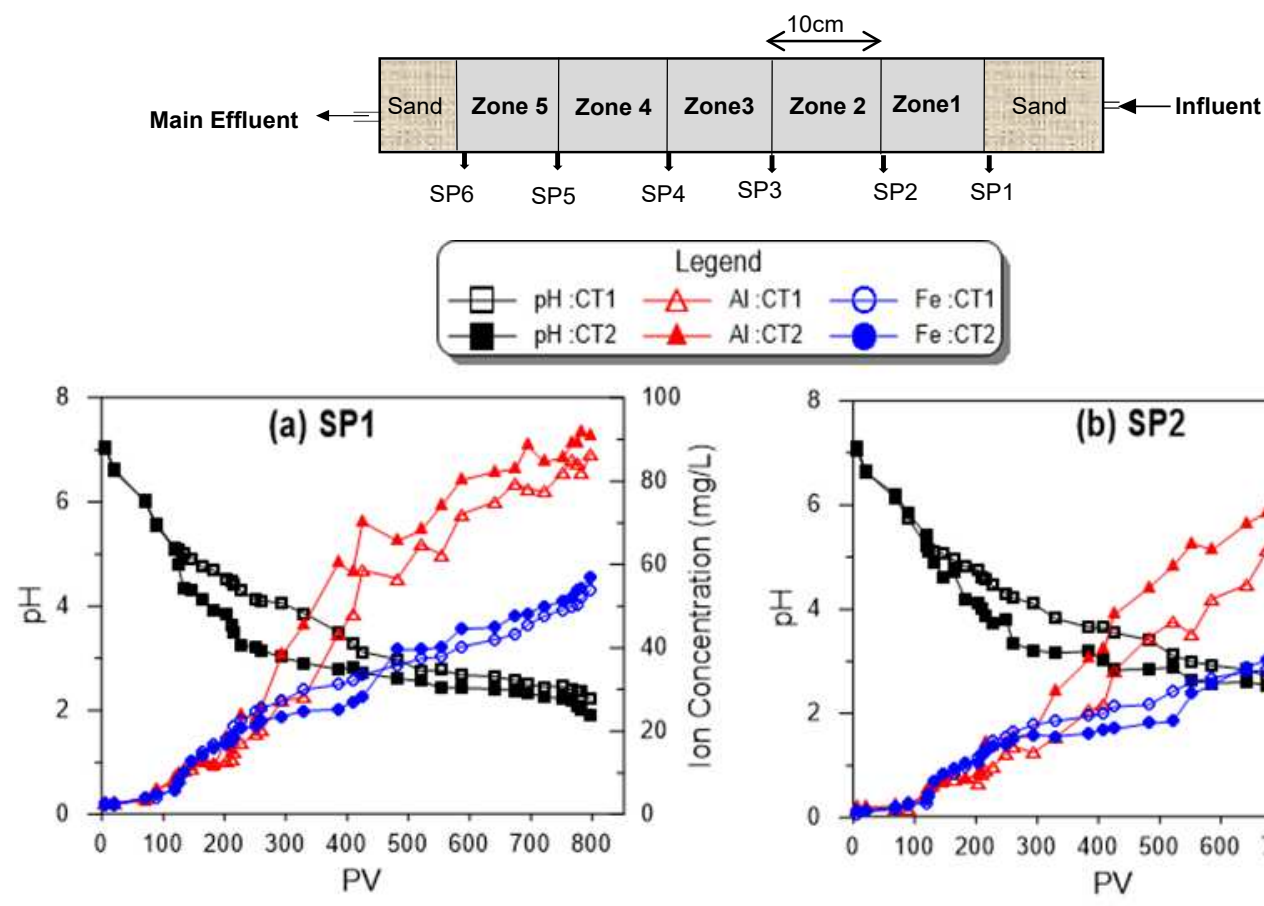

egend

$\begin{array}{r}-\mathrm{Al}: \mathrm{CT} 1 \\ -\mathrm{Al}: \mathrm{CT} 2\end{array}-\mathrm{Fe}: \mathrm{CT} 1$
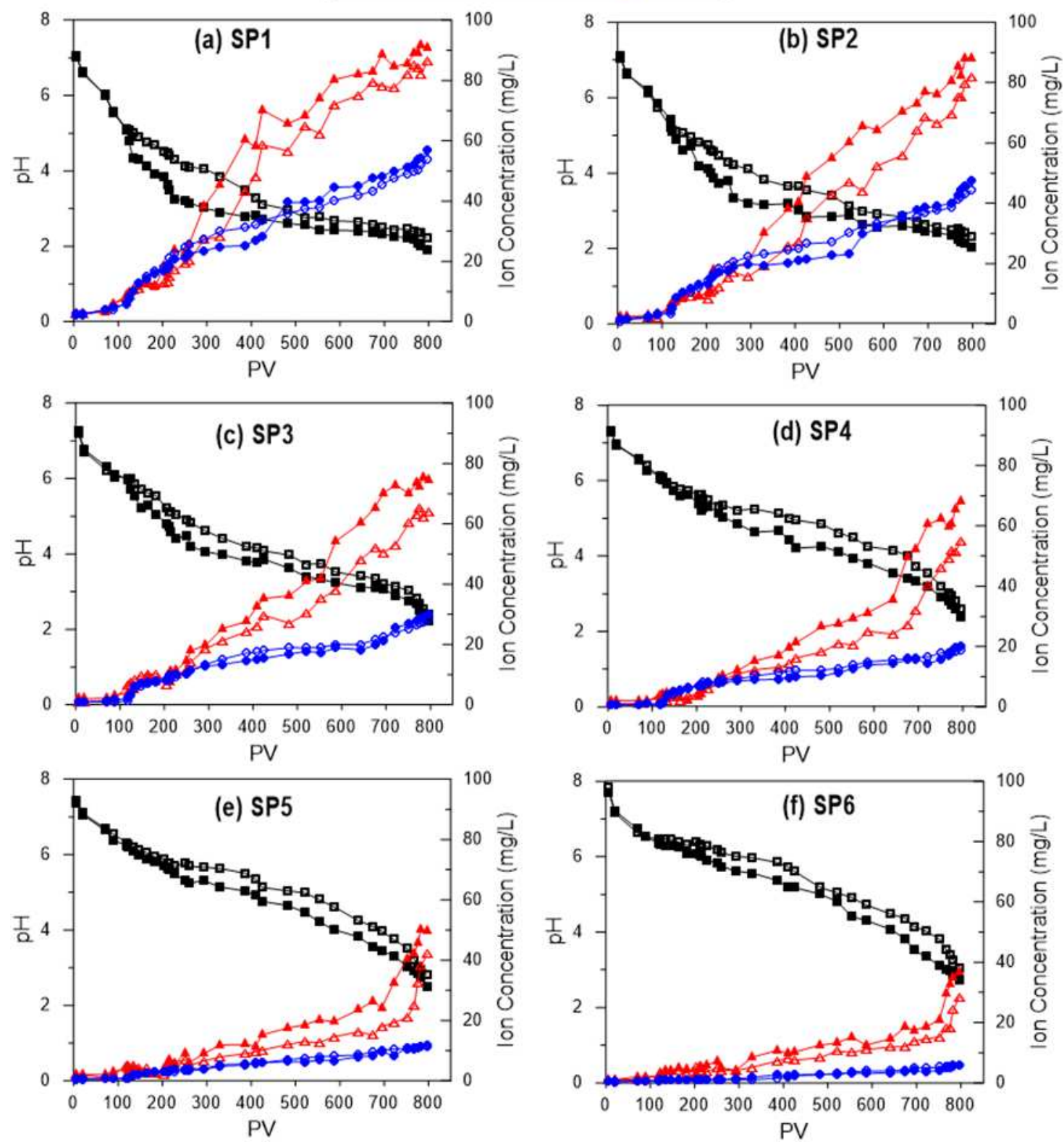

Figure 4. Temporal variations of $\mathrm{pH}$, dissolved Total $\mathrm{Fe}$ and $\mathrm{Al}^{3+}$ along the length of the columns 



Figure 5. Variations in the effluent parameters with time a) $\mathrm{pH}$, dissolved Total $\mathrm{Fe}$ and $\mathrm{Al}^{3+}$ b) Oxidation Reduction Potential (ORP) 

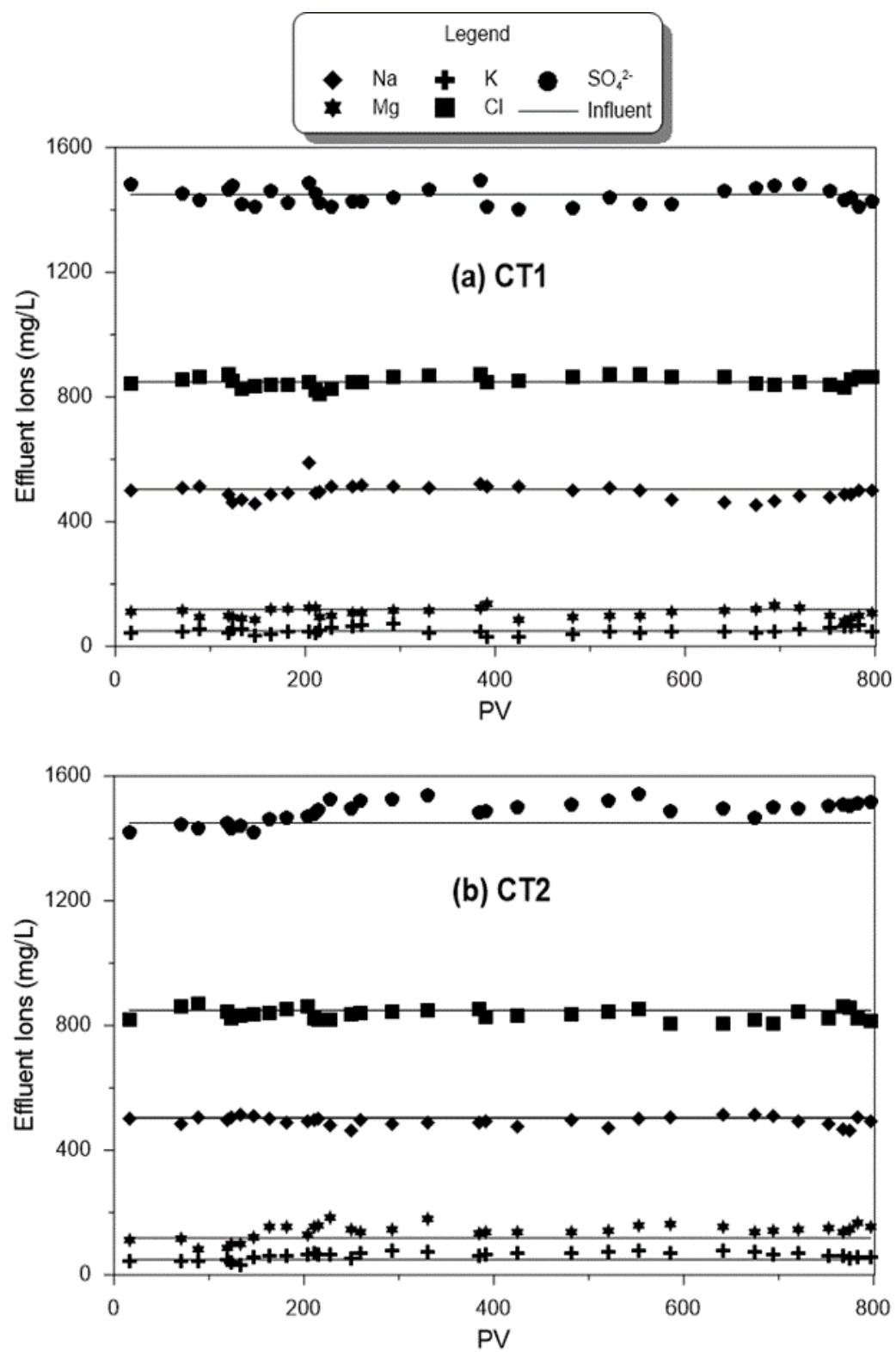

Figure 6. Concentrations of other ions dissolved in the column effluent: a) CT1 b) CT2 




Figure 7. Formation of $\mathrm{Fe}$ and $\mathrm{Al}$ precipitates along the columns with time 


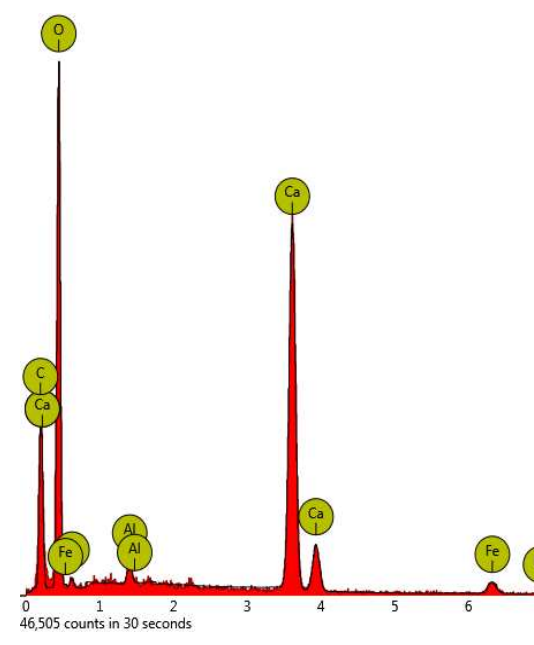

(a)
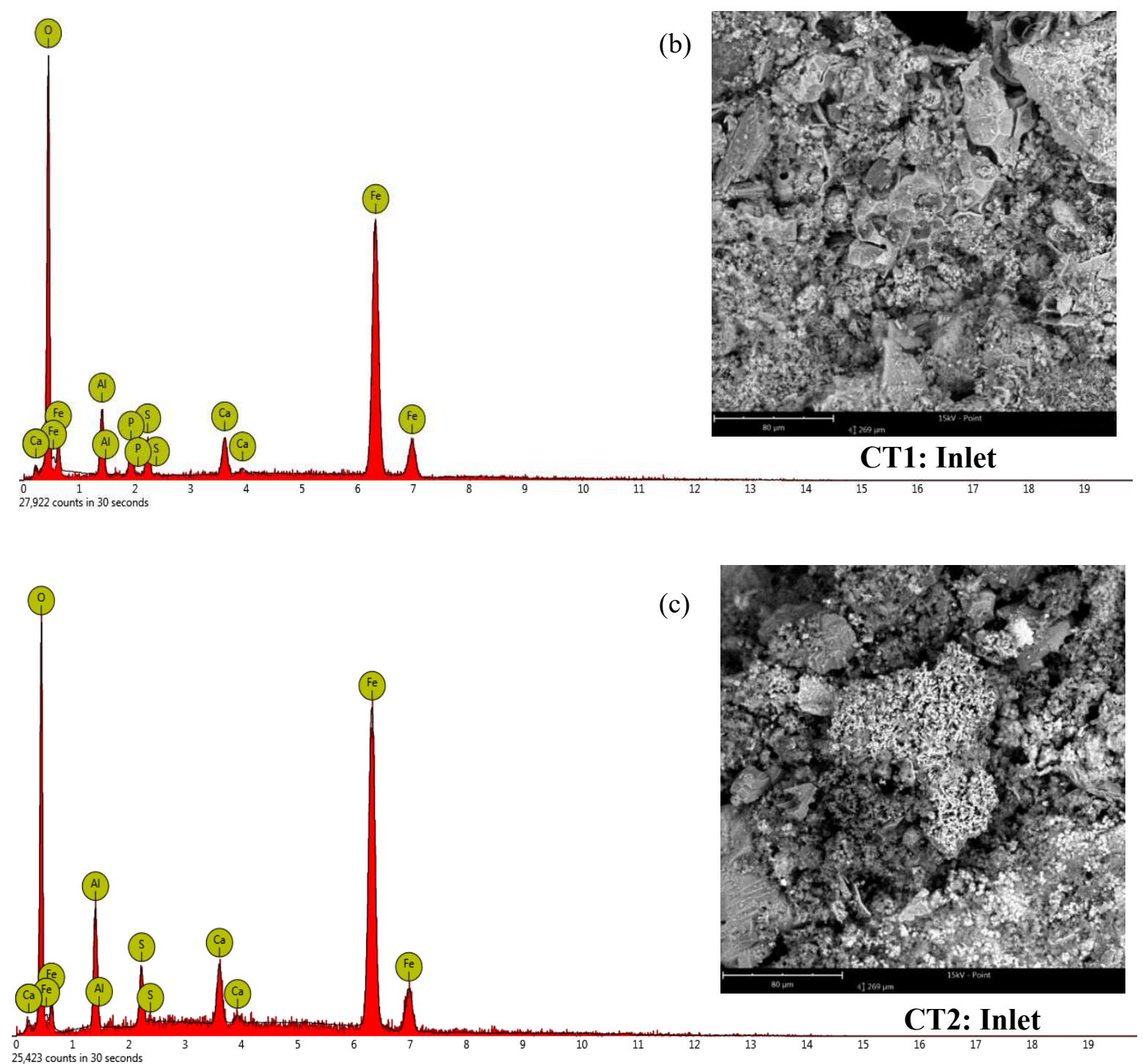

Figure 8. Energy-dispersive X-ray spectroscopy (EDS) analysis of limestone (a) Fresh limestone (b) Particles extracted from CT1 inlet (c) Particles extracted from CT2 inlet 


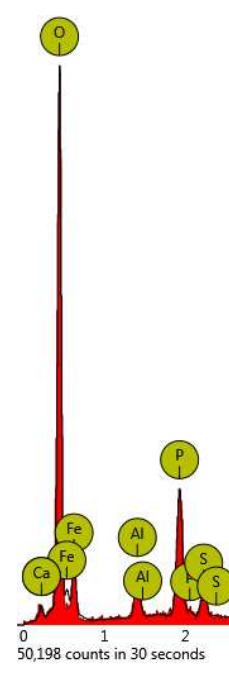

(a)



CT1: Middle Zone

(b)


CT2: Middle Zone

Figure 9. Energy-dispersive X-ray spectroscopy (EDS) analysis of extracted coated particles from middle area of the column (a) CT1 (b) CT2 


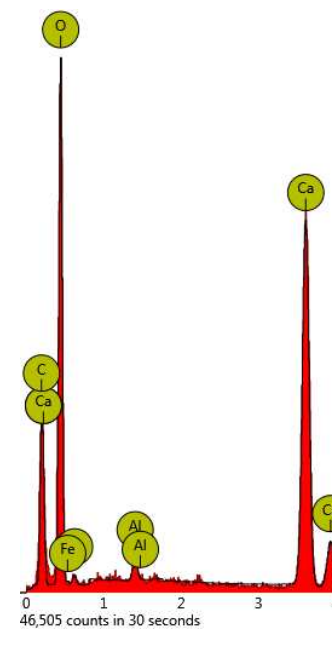

(a)

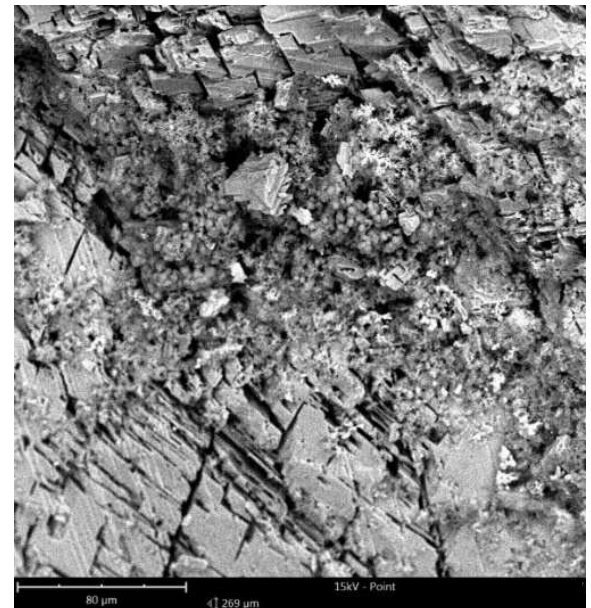

CT1: Outlet

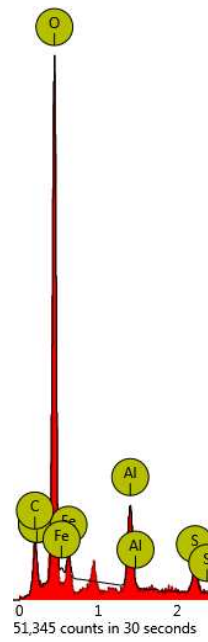

(b)

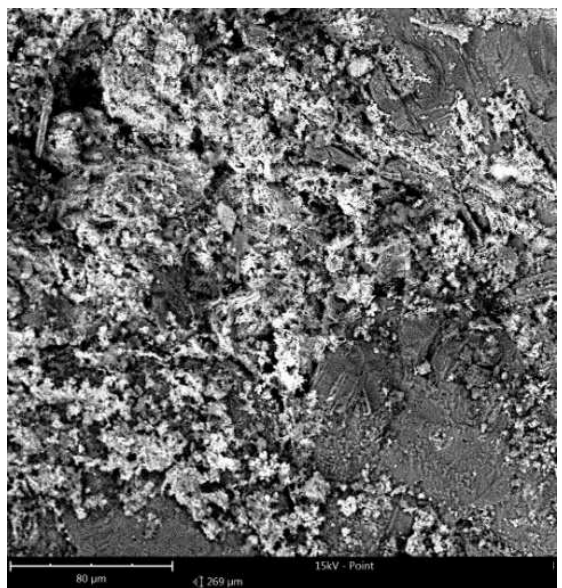

Figure 10. Energy-dispersive X-ray spectroscopy (EDS) analysis of extracted coated particles from outlet of columns (a) CT1 (b) CT2 

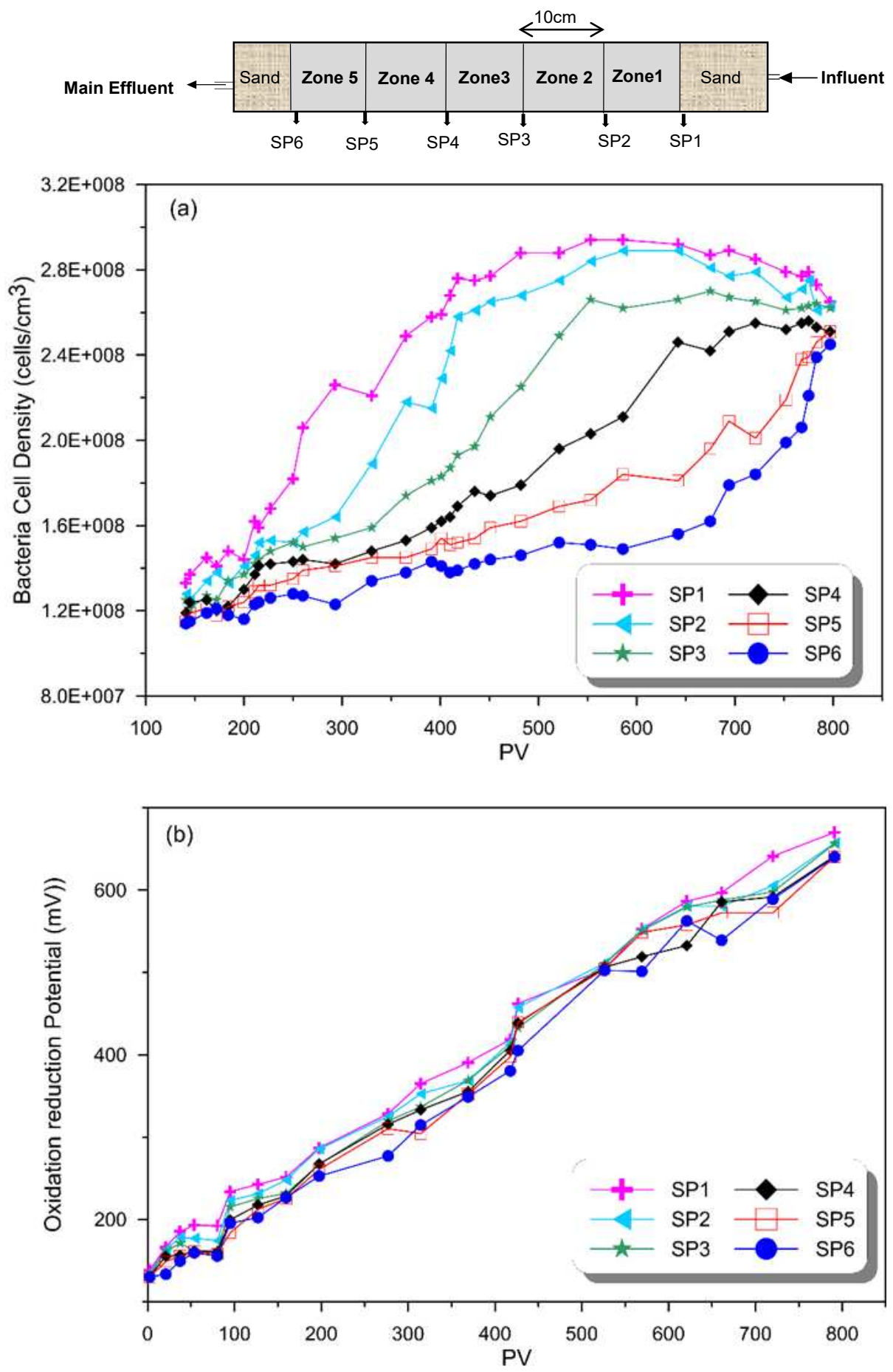

Figure 11: (a) Bacteria cell density of sampling effluents along CT2 (b) ORP variation in CT2 


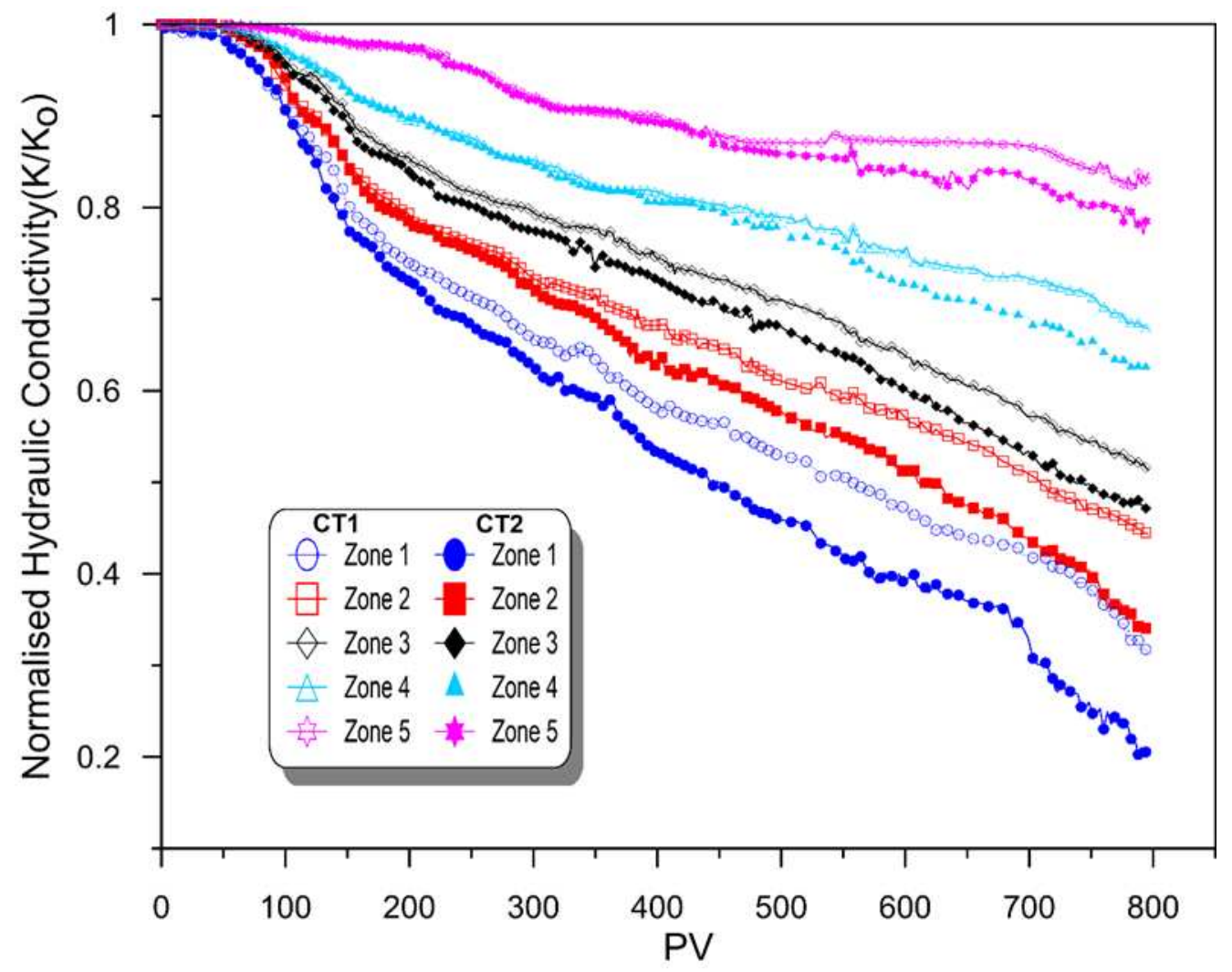

Figure 12. Variations of normalised hydraulic conductivity along the length of CT1 and CT2 




Figure 13. Variations of hydraulic head at different distances from CT2 inlet 


\section{References}

Arkesteyn, G. J. 1980. "Pyrite oxidation in acid sulphate soils: The role of microorganisms." Plant and soil, 54(1), 119-134.

ASTM (2000) D 2487: Standard Practice for classification of soils for engineering purposes (Unified Soil Classification System). ASTM International. West Conshohocken, PA, USA.

Baveye, P. \& Valocchi, A. 1989. “An evaluation of mathematical models of the transport of biologically reacting solutes in saturated soils and aquifers." Water Resources Research, 25(6), 1413-1421.

Benner, S., Blowes, D. W., Gould, W. D., Herbert, R. B. \& Ptacek, C. J. 1999. “Geochemistry of a permeable reactive barrier for metals and acid mine drainage.” Environmental Science \& Technology, 33(16), 2793-2799.

Blowes, D. W., Ptacek, C. J., Jambor, J. L., and Weisener, C. G. 2003. "The Geochemistry of Acid Mine Drainage." Treatise on Geochemistry, H. D. H. a. K. K. Turekan, ed., Elsevier Science Ltd, Oxford, 149-204.

Chen-Charpentier, B. 1999. "Numerical simulation of biofilm growth in porous media." Journal of computational and applied mathematics, 103(1), 55-66.

Clement, T., Hooker, B. \& Skeen, R. 1996.” Macroscopic models for predicting changes in saturated porous media properties caused by microbial growth.” Ground Water, 34(5), 934-942.

Dent, D.L. and Pons, L.J., 1995. “A world perspective on acid sulphate soils.” Geoderma, 67(3-4), pp.263-276.

Ekolu, S. O. \& Bitandi, L. K. 2018. "Prediction of Longevities of ZVI and Pervious Concrete Reactive Barriers Using the Transport Simulation Model.” Journal of Environmental Engineering, 144, 04018074.

Eyring, H. 1935. “The activated complex and the absolute rate of chemical reactions.” Chemical Reviews, 17(1), $65-77$.

Gavaskar, A. R. 1999. "Design and construction techniques for permeable reactive barriers." Journal of hazardous materials, 68(1-2), 41-71.

Gibert, O., De Pablo, J., Luis Cortina, J. \& Ayora, C. 2003. "Evaluation of municipal compost/limestone/iron mixtures as filling material for permeable reactive barriers for in-situ acid mine drainage treatment." Journal of Chemical Technology and Biotechnology, 78(5), 489-496.

Golab, A. N., Indraratna, B., Peterson, M. A. \& Hay, S. 2006a. "Design of a Permeable Reactive Barrier to Remediate Acidic Groundwater.” ASEG Extended Abstracts, 2006(1), 1-3. 
Golab, A. N., Peterson, M. \& Indraratna, B. 2006b. "Selection of potential reactive materials for a permeable reactive barrier for remediating acidic groundwater in acid sulphate soil terrains." Quarterly Journal of Engineering Geology and Hydrogeology, 39(2), 209-223.

Harbaugh, A. W. 2005. "MODFLOW-2005". the US Geological Survey modular ground-water model: the ground-water flow process, US Department of the Interior, US Geological Survey Reston, VA, USA.

Indraratna B, Medawela SK, Athuraliya S, Heitor A, Baral P. 2019, "Chemical clogging of granular media under acidic groundwater“. Environmental Geotechnics, Special Issue: Testing and Modelling of Complex Rockfill Material (Accepted), doi: 10.1680/jenge.18.00143.

Indraratna, B., Pathirage, P. U. \& Banasiak, L. J. 2014a. "Remediation of acidic groundwater by way of permeable reactive barrier." Environmental Geotechnics,4(4), 284-298

Indraratna, B., Pathirage, P. U., Rowe, R. K. \& BanasiaK, L. 2014b. “Coupled hydro-geochemical modelling of a permeable reactive barrier for treating acidic groundwater." Computers and Geotechnics, 55, 429-439.

Indraratna, B., Regmi, G., Nghiem, L. D. \& Golab, A. 2009. "Performance of a PRB for the remediation of acidic groundwater in acid sulfate soil terrain." Journal of geotechnical and geoenvironmental engineering, 136(7), 897-906.

Johnson, R., Blowes, D., Robertson, W. \& JamboR, J. 2000. “The hydrogeochemistry of the Nickel Rim mine tailings impoundment, Sudbury, Ontario.” Journal of Contaminant Hydrology, 41(1-2), 49-80.

Jurjovec, J., Ptacek, C. J. \& BloweS, D. W. 2002. “Acid neutralization mechanisms and metal release in mine tailings: a laboratory column experiment." Geochimica et Cosmochimica Acta, 66(9), 1511-1523.

Komnitsas, K., Bartzas, G. \& Paspaliaris, I. 2004. "Efficiency of limestone and red mud barriers: laboratory column studies." Minerals engineering, 17(2), 183-194.

Li, L., Benson, C. H. \& Lawson, E. M. 2005. "Impact of mineral fouling on hydraulic behavior of permeable reactive barriers." Ground Water, 43(4), 582-596.

Li, L., Benson, C. H. \& lawson, E. M. 2006. "Modeling porosity reductions caused by mineral fouling in continuous-wall permeable reactive barriers.” Journal of Contaminant Hydrology, 83(1-2), 89-121.

Macdonald, D. \& Clark, R. 1970. "The oxidation of aqueous ferrous sulphate by Thiobacillus ferrooxidans." The Canadian Journal of Chemical Engineering, 48(6), 669-676. 
Mayer, K., Benner, S. \& BloweS, D. 2006. "Process-based reactive transport modeling of a permeable reactive barrier for the treatment of mine drainage." Journal of contaminant hydrology, 85(3-4), 195-211.

Mcgoran, C., Duncan, D. \& Walden, C. 1969. "Growth of Thiobacillus ferrooxidans on various substrates.” Canadian journal of Microbiology, 15(1), 135-138.

Molz, F. J., WiddowsoN, M. \& Benefield, L. 1986. "Simulation of microbial growth dynamics coupled to nutrient and oxygen transport in porous media." Water Resources Research, 22(8), 1207-1216.

Monod, J. 1949. “The growth of bacterial cultures.” Annual Reviews in Microbiology, 3, 371-394.

Nemati, M., Harrison, S., Hansford, G. \& Webb, C. 1998. "Biological oxidation of ferrous sulphate by Thiobacillus ferrooxidans: a review on the kinetic aspects.” Biochemical engineering journal, 1(3), 171-190.

Nordstrom, D.K., 1982. "Aqueous pyrite oxidation and the consequent formation of secondary iron minerals", Acid Sulfate weathering. Soil Science Society of America, pp. 37-56

Obiri-Nyarko, F., Grajales-Mesa, S. J. \& Malina, G. 2014. “An overview of permeable reactive barriers for in situ sustainable groundwater remediation." Chemosphere, 111, 243-259.

Olem, H. \& Unz, R. F. 1977. “Acid mine drainage treatment with rotating biological contactors.” Biotechnology and bioengineering, 19(10), 1475-1491.

Rawlings, D. E. 2002. "Heavy metal mining using microbes.” Annual Reviews in Microbiology, 56(1), 65-91.

Regmi, G., Indraratna, B., Nghiem, L. D., Golab, A. \& Prasad, B. G. 2010. “Treatment of acidic groundwater in acid sulfate soil terrain using recycled concrete: column experiments." Journal of Environmental Engineering, 137(6), 433-443.

Shulter, M.L \& Kargi, F. 2000. "Bioprocess engineering basic concept.” New Delhi: Parentice-Hall of India Pvt Ltd.

Singer, P. C. \& Stumm, W. 1970. “Acidic mine drainage: the rate-determining step”. Science, 167(3921), 11211123.

Steefel, C. I. \& Lasaga, A. C. 1994. "A coupled model for transport of multiple chemical species and kinetic precipitation/dissolution reactions with application to reactive flow in single phase hydrothermal systems." American Journal of science, 294(5), 529-592. 
Taylor, S. W. \& Jaffé, P. R. 1990. "Biofilm Growth and the Related Changes in the Physical Properties of a Porous Medium 1. Experimental Investigation.” Water resources research, 26(9), 2153-2159.

Tuovinen, O. H. \& Kelly, D. P. 1973. "Studies on the growth of Thiobacillus ferrooxidans." Archiv für Mikrobiologie, 88(4), 285-298.

White, I., Melville, M., Wilson, B. \& Sammut, J. 1997. "Reducing acidic discharges from coastal wetlands in eastern Australia." Wetlands Ecology and Management, 5(1), 55-72. 